Research Data Centre (FDZ)

of the German Federal

Employment Agency (BA)

at the Institute for

Employment Research (IAB)

\title{
FDZ-Datenreport
}

02/2017

\section{IZA/IAB Linked Evaluation Dataset 1993-2010}

Johanna Eberle,

Robert Mahlstedt, Alexandra Schmucker 


\section{IZA/IAB Linked Evaluation Dataset 1993-2010}

Johanna Eberle (Institute for Employment Research), Robert Mahlstedt (Institute of Labor Economics), Alexandra Schmucker (Institute for Employment Research)

Die FDZ-Datenreporte beschreiben die Daten des FDZ im Detail. Diese Reihe hat somit eine doppelte Funktion: Zum einen stellen Nutzerinnen und Nutzer fest, ob die angebotenen Daten für das Forschungsvorhaben geeignet sind, zum anderen dienen sie zur Vorbereitung der Auswertungen.

FDZ-Datenreporte (FDZ data reports) describe FDZ data in detail. As a result, this series of reports has a dual function: on the one hand, users can assess whether the data offered is suitable for their research task; on the other, the information can be used to prepare analyses. 
Abstract

1 Introduction and outline

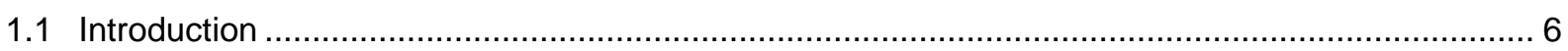

1.2 Data use

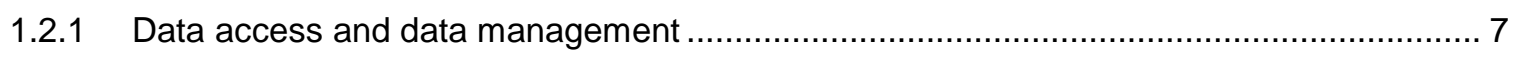

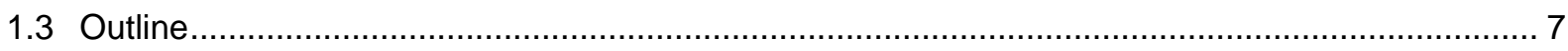

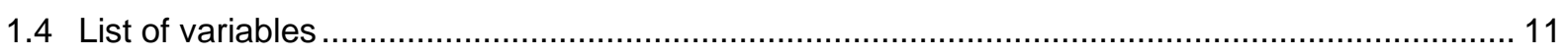

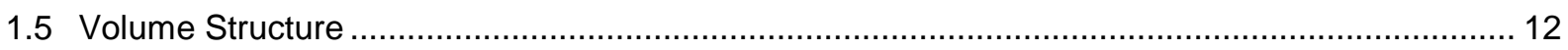

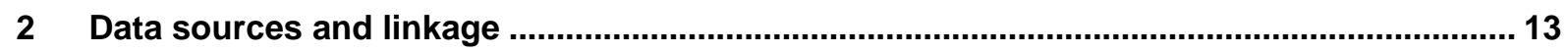

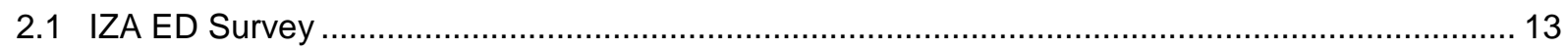

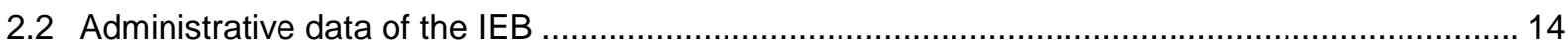

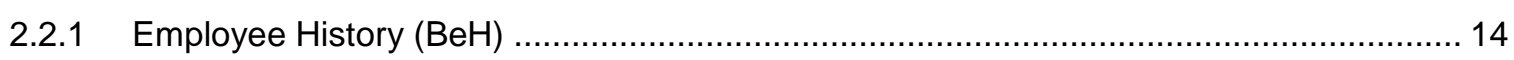

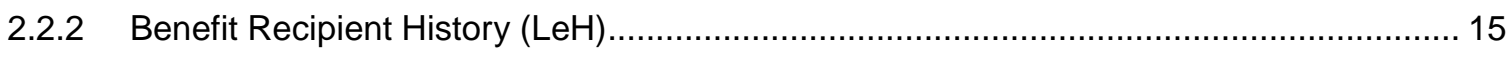

2.2.3 Unemployment Benefit II Recipient History (LHG / XLHG) ........................................... 15

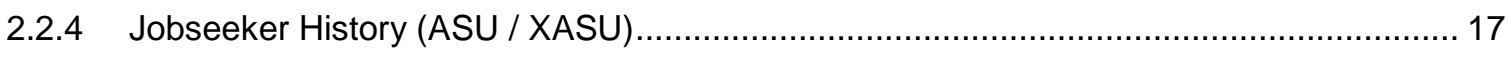

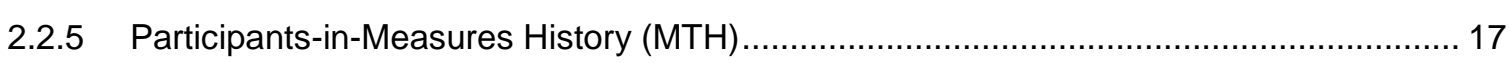

3 Data preparation and sampling procedure

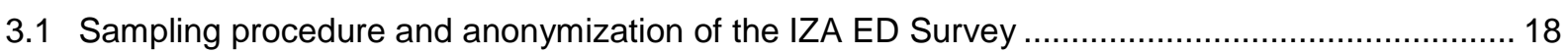



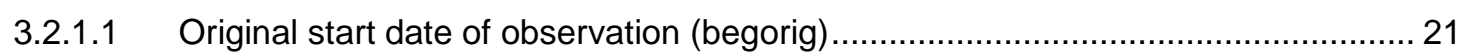

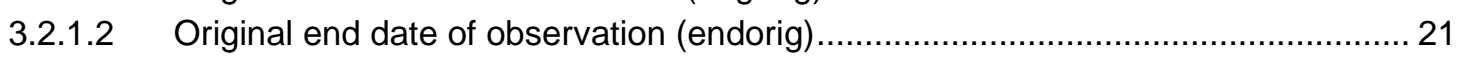

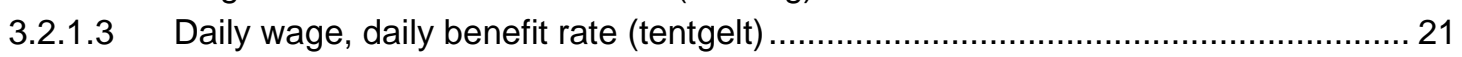

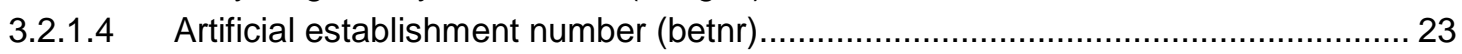

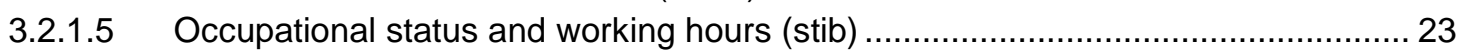

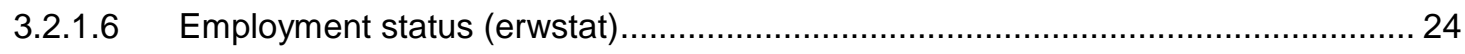

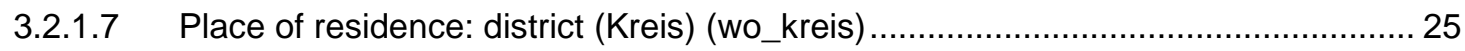

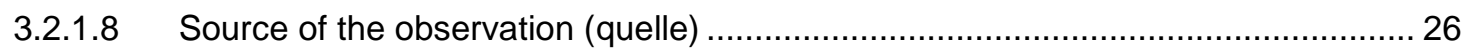

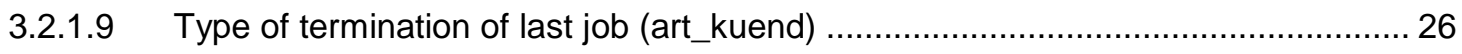

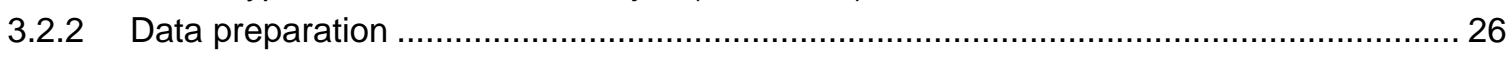





4 Data quality and problems

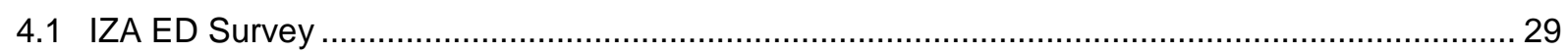

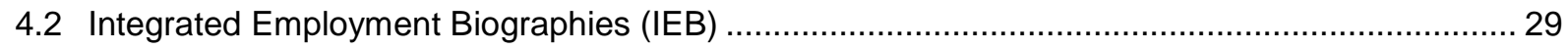

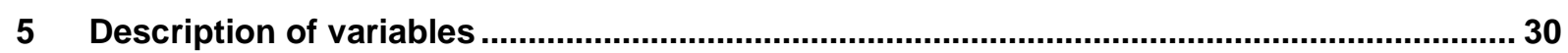

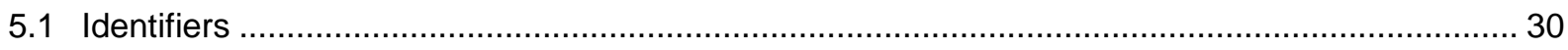

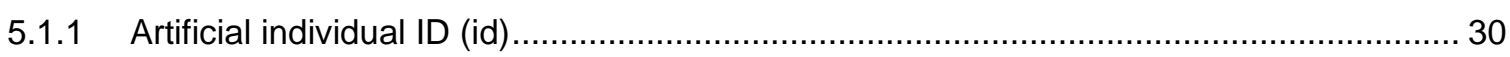

5.1.2 Month of entry into unemployment (eintritt) …....................................................... 31

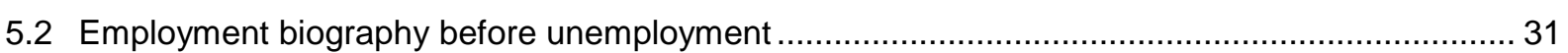




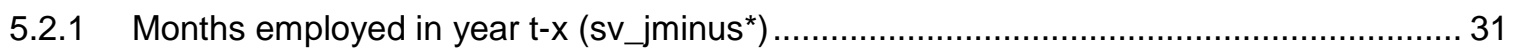

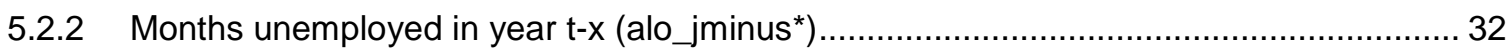

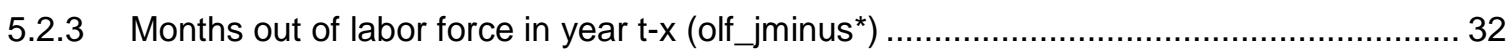

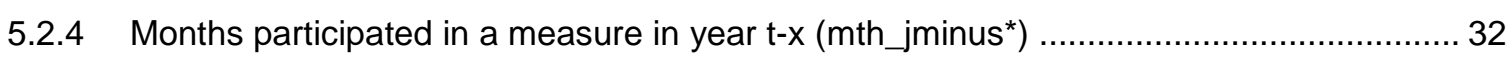

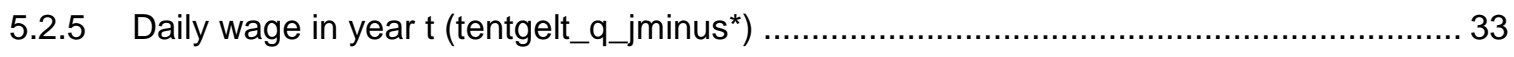

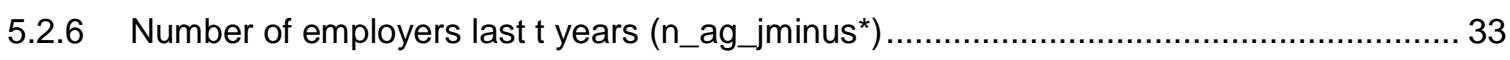

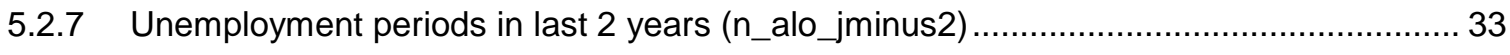

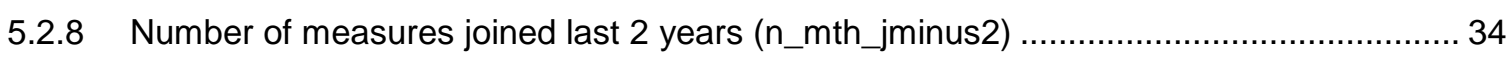

5.2.9 Unemployment duration last episode of unemployment (dauer_alo_bev) ....................... 34

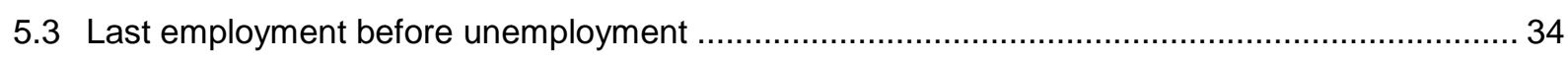

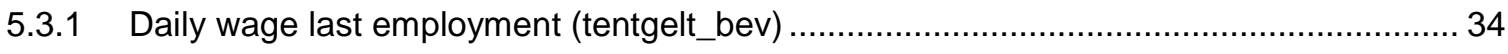

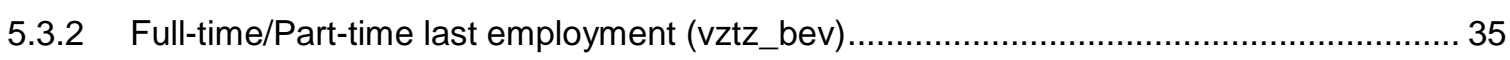

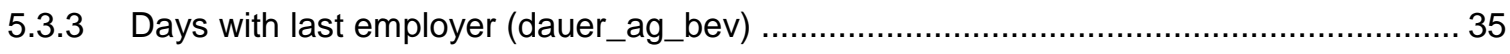



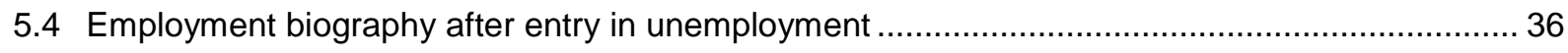

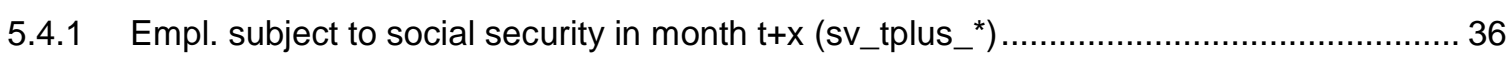

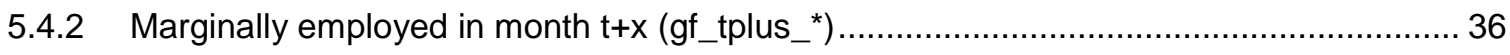

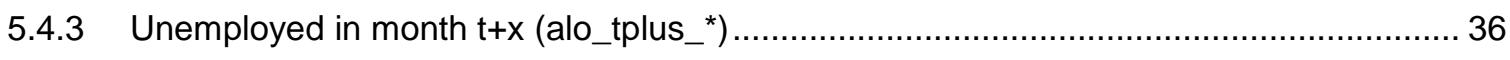

5.4.4 Hours worked per week in month $\mathrm{t}+\mathrm{x}$ (azeit_kat_tplus_*) ................................................ 37

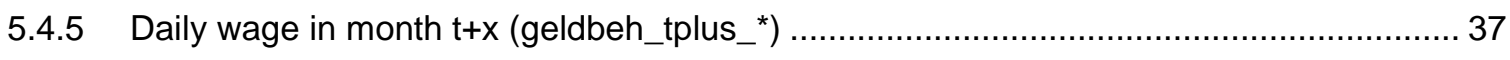

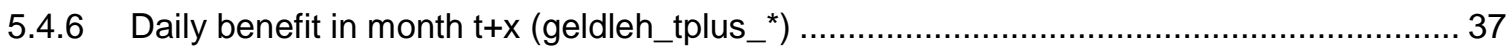

5.4.7 Change of home district during first $x$ months (umzug_tplus*) ...................................... 38

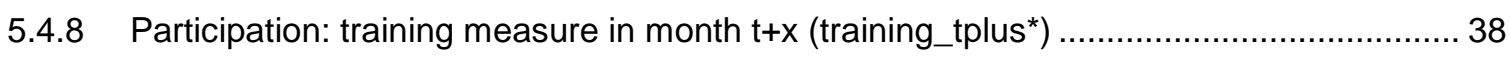

5.4.9 Participation: promotion of further vocational training in month $\mathrm{t}+\mathrm{x}$ (fbw_tplus ${ }^{\star}$ ).............. 38

5.4.10 Month of first receipt of wage subsidy after entry into unemployment (Ikz_beg).............. 39

5.4.11 Number of months with receipt of wage subsidy (Ikz_gesamt) ................................... 39

5.4.12 Month of first receipt of start-up subsidy after entry into unemployment (gz_beg)........... 39

5.4.13 Number of months with receipt of start-up subsidy (gz_gesamt) ................................. 40

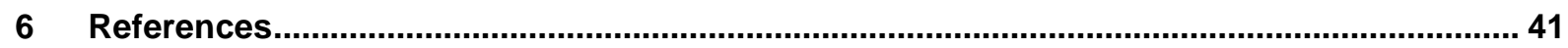

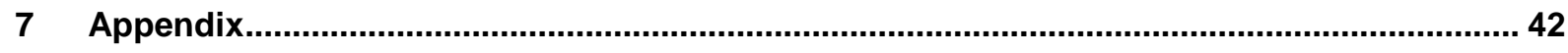

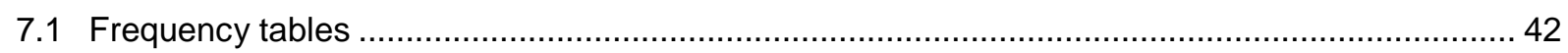

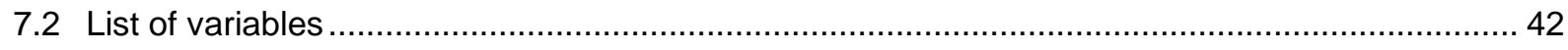

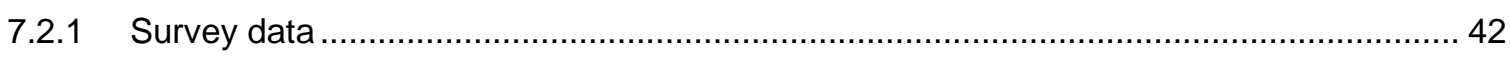

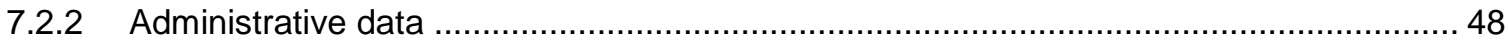

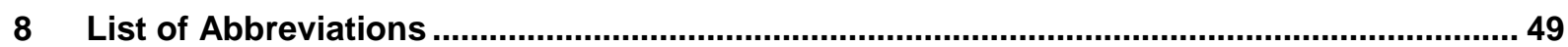




\title{
Zusammenfassung
}

Der vorliegende Datenreport beschreibt das faktisch anonymisierte Scientific Use File „IZA/IAB Linked Evaluation Dataset 1993-2010“.

\begin{abstract}
This data report provides a description of the factual anonymous Scientific Use File 'IZA/IAB Linked Evaluation Dataset 1993-2010'.
\end{abstract}

Keywords: German administrative micro data, labour market data, data manual

We would like to thank our colleagues in the Research Data Centre (FDZ) who were involved in the working group on the Sample of Integrated Labour Market Biographies as well as the ITM division of the Institute for Employment Research for their cooperation and support. In particular, we could like to thank Markus Köhler for valueable comments and information regarding the participation histories and Steffen Künn for his contribution on the preparation of the survey data. If possible, the data report refers to the FDZ data report 01/2013 (vom Berge et al. 2013) on the Sample of Integrated Labour Market Biographies (SIAB) and the FDZ data report 03/2015 (Eberle and Schmucker, 2015) on the IZA/IAB Administrative Evaluation Dataset. Additionally, individual passages from IAB-internal data documentations by IAB ITM were adopted. 


\section{Introduction and outline}

\subsection{Introduction}

The present data report describes the factual anonymous individual-level data of the IZA/IAB Linked Evaluation Dataset 1993-2010. It was created in the context of the research project "Evaluation der Effektivität der Hauptinstrumente der aktiven Arbeitsmarktpolitik nach $\S 3$ SGB III" (Evaluation of the effectiveness of the main instruments of active labour market policy in accordance with German Social Code Book III) by the Institute of Labor Economics (IZA) in Bonn. In cooperation with the Institute for Employment Research in Nuremberg, an extensive data base for analysing the effectiveness of active labour market policy measures was compiled. From the Integrated Employment Biographies (IEB) of the IAB, which comprise administrative individual-level data about the employment situation from the reporting procedure for social security and about benefits received, job search and participation in measures from the operational business of the Federal Employment Agency, a random sample of persons who entered unemployment between January 2001 and December 2008 was taken. For selected persons with entries in unemployment between June 2007 and May 2008, an additional telephone interview was carried out on behalf of IZA. In total, about 17,400 people were interviewed. These persons were asked for their consent to link the survey data with the information available at the IAB: 15,274 persons gave their consent and finally the data of 15,173 individuals could be matched.

This linked dataset is now being offered as a Scientific Use File (SUF) by the Research Data Centre of the BA in the IAB (FDZ) in cooperation with the International Data Service Center of the IZA (IDSC). The FDZ provides external researchers with only the administrative individuallevel data, while the survey data is supplied by the IDSC. Hence researchers who comply with the requirements of both institutions can receive the two parts of the IZA/IAB Linked Evaluation Dataset and link them.

The administrative data in the Linked Evaluation Dataset differs from the weakly-anonymized IZA/IAB Administrative Evaluation Dataset (AED) which provides detailed information on the employment biographies on a daily basis. Due to the requirements of the factual anonymization the information in the linked dataset had to be reduced significantly. Hence the administrative data have been reshaped so that information on the period before unemployment is provided on a yearly basis and information on the period after entering unemployment on a monthly basis. The variables concerning the participation in active labour market programmes are reduced as well. Furthermore some variables of the survey data have to be deleted or values have to be pooled into new categories. 
The IZA/IAB Linked Evaluation Dataset offers a new perspective for empirical labour market research. One the one hand, it is suitable for an evaluation of selected active labour market policy instruments, like training programs or wage subsidies. But on the other hand, the combination of rich individual characteristics and longitudinal data provides an ideal base for an empirical analysis of many other aspects of the transition process from unemployment to employment including the interplay of search behavior, personality, psychological factors, social networks, attitudes and labour market outcomes, while detailed employment biographies, before entering unemployment, allow to account for individual heterogeneity. Due to the special sampling design with focus on enterances into unemployment from an existing employment, the sample is not representative for job-seeking persons in general.

\subsection{Data use}

\subsubsection{Data access and data management}

The IZA/IAB Linked Evaluation Dataset in the factual anonymous version is available as SUF at the FDZ and the IDSC. In order to be able to use the data, it is first necessary to submit an application to the FDZ and the IDSC. The application will be reviewed in the FDZ and the IDSC. When approval has been granted, a data use agreement is concluded with the researcher's institution. Details on applying for the dataset and possibilities for data processing can be found on the websites of the FDZ and the IDSC.

The data contain German as well as English labels. By means of the Stata command label language en or label language de, it is possible to switch between the languages. The datasets have a modular structure, are stored in several files and can be linked using the variable 'id'.

\subsection{Outline}

The IZA/IAB Linked Evaluation Dataset contains survey and administrative data for 15,173 persons having entered unemployment between June 2007 and May 2008. The adminsitrative data are based on records from the integrated employment biographies. Several modular datasets with additional variables from the survey can be merged to the core dataset. 
Table 1: Outline of the IZA/IAB Linked Evaluation Dataset

\begin{tabular}{|c|c|}
\hline $\begin{array}{l}\text { Topics/characteristics } \\
\text { categories }\end{array}$ & $\begin{array}{l}\text { Identifiers: } \\
\text { Artificial individual ID } \\
\text { Survey data } \\
\text { Longitudinal information on current professional situation: } \\
\text { school attendance, professional training, employment, unem- } \\
\text { ployment, other activities } \\
\text { Cross-sectional information: employment history, migration } \\
\text { background, school and qualification, job search, personality, } \\
\text { health, social networks, household composition, debts, cultural } \\
\text { techniques, life satisfaction, contact to employment agency, un- } \\
\text { employment benefit receipt, living circumstances } \\
\text { Administrative data } \\
\text { Employment biography after entry into unemployment: employ- } \\
\text { ment status, working time and daily earnings for a period of } 30 \\
\text { months after the entry into unemployment, relocation behaviour, } \\
\text { participation in active labor market programs (short-term train- } \\
\text { ing, long-term training, wage subsidies, start-up subsidies) } \\
\text { Employment biography before entry into unemployment: em- } \\
\text { ployment status, participation in active labor market programs, } \\
\text { earnings, no. of employers up to } 10 \text { years before the entry. } \\
\text { Information on last employment: earnings, type of job (full- or } \\
\text { part-time), time with last employer, reason for termination }\end{array}$ \\
\hline Data unit & $\begin{array}{l}\text { Survey data: } \\
\text { Selected sample of individuals entering unemployment identified } \\
\text { in administrative records. } \\
\text { Administrative individual data: } \\
\text { Employees covered by social security (including marginal em- } \\
\text { ployment since 1999), benefit recipients, job-seekers, (partici- } \\
\text { pants in active labour market programmes) }\end{array}$ \\
\hline Case numbers & $\begin{array}{l}\text { Survey data: } \\
17,393 \text { survey participants out of those } \\
15,271 \text { agree to merge with administrative data } \\
98 \text { individuals could not be uniquely identified in the administra- } \\
\text { tive records } \\
\text { Administrative data: } \\
15,173 \text { individuals }\end{array}$ \\
\hline
\end{tabular}




\begin{tabular}{|c|c|}
\hline Period covered & $\begin{array}{l}\text { Survey data: } \\
2007-2011 \\
\text { Adminsitrative data: } \\
\text { The period covered depends on the data source: } \\
\text { Employment: } 1993-2010 \\
\text { Benefit receipt: } 1993-2011 \\
\text { Job-search: } 1997-2011 \\
\text { Participation in measures: } 2000-2011\end{array}$ \\
\hline Time reference & $\begin{array}{l}\text { Survey data: } \\
\text { Date of interview, longitudinal data prospective up to } 36 \text { months } \\
\text { after interview, cross-sectional data collected at } 4 \text { points in time } \\
\text { (see wave 1-3 and interim wave) } \\
\text { Administrative data: } \\
\text { employment biographies detailed to the year or month }\end{array}$ \\
\hline Regional structure & $\begin{array}{l}\text { Local unemployment rates in month of entry into unemployment } \\
\text { on employment agency district level. } \\
\text { Dummy variable indicating relocation on county within } 12 / 30 \\
\text { months after entry. }\end{array}$ \\
\hline Territorial accolcation & $\begin{array}{l}\text { Survey data: } \\
\text { Regional allocation as of } 05 / 2007 \\
\text { Administrative data: } \\
\text { Original regional allocation; } \\
\text { Except employment: regional allocation as of 31/12/2010 }\end{array}$ \\
\hline Survey design & $\begin{array}{l}\text { The contact information of individuals entering unemployment } \\
\text { was drawn from the monthly unemployment inflow statistic of } \\
\text { the Federal Employment Agency. } \\
\text { Restrictions implemented before the interview: } \\
\text { 1) Age restriction: } 16-54 \text { years at entry into unemployment } \\
\text { 2) Exclusion of unemployment benefit type II recipients } \\
\text { 3) Exclusion of re-entries into unemployment after a period of } \\
\text { sickness or participation in ALMP programs } \\
\text { Restrictions implemented during the interview: } \\
\text { 4) Verification of unemployment entry and previous activities by } \\
\text { respondents } \\
\text { 5) Exclusion of "pseudo entries": individuals who signed a con- } \\
\text { tract for a new job already at entry into unemployment } \\
\text { The initial sample of } 17,393 \text { individuals consists of } 12 \text { monthly } \\
\text { cohorts that were interviewed between } 7 \text { and } 14 \text { months after }\end{array}$ \\
\hline
\end{tabular}




\begin{tabular}{|c|c|}
\hline & $\begin{array}{l}\text { the entry into unemployment (first wave). An interim wave was } \\
\text { conducted after } 6 \text { months for a subsample of 2,548 individuals. } \\
\text { Out of the initial sample 8,914 respondents participated in the } \\
\text { second wave, } 12-15 \text { months after the entry, and 5,785 rep- } \\
\text { sondents participated also in the third wave, 36-39 months after } \\
\text { the entry. }\end{array}$ \\
\hline Institutions involved & infas - Institute for Applied Social Sciences \\
\hline $\begin{array}{l}\text { Frequency of data col- } \\
\text { lection }\end{array}$ & $\begin{array}{l}\text { Survey data: } \\
\text { Completed } \\
\text { Adminsitrative data: } \\
\text { Constant }\end{array}$ \\
\hline $\begin{array}{l}\text { File organisation, format } \\
\text { and size }\end{array}$ & $\begin{array}{l}\text { Administrative data: } 1 \text { file (Stata: approx. } 5 \text { MB; SPSS: approx. } \\
4 \mathrm{MB} \text { ). } \\
\text { Survey data: } 7 \text { files (Stata: approx. } 48 \text { MB; SPSS: approx.. 36,2 } \\
\text { MB) } \\
\text { Format: Stata, SPSS }\end{array}$ \\
\hline Data access & Scientific use file \\
\hline $\begin{array}{l}\text { Degree of anonymisa- } \\
\text { tion }\end{array}$ & Factually anonymous \\
\hline Sensitive characteristics & None \\
\hline $\begin{array}{l}\text { Specifications for quot- } \\
\text { ing the data and data } \\
\text { documentation }\end{array}$ & $\begin{array}{l}\text { Data: } \\
\text { 'This study uses the factually anonymous data of the IZA/IAB } \\
\text { Linked Evaluation Dataset 1993-2010. Data access was pro- } \\
\text { vided via a Scientific Use File supplied by the Research Data } \\
\text { Centre (FDZ) of the German Federal Employment Agency (BA) } \\
\text { at the Institute for Employment Research (IAB) and the Interna- } \\
\text { tional Data Service Center (IDSC) of the Institute of Labor Eco- } \\
\text { nomics (IZA).' } \\
\text { Documentation of data } \\
\text { Eberle, Johanna; Mahlstedt, Robert; Schmucker, Alexandra } \\
\text { (2017): IZA/IAB Linked Evaluation Dataset 1993-2010. FDZ } \\
\text { Data report, 02/2017 (en), Nuremberg }\end{array}$ \\
\hline
\end{tabular}

For details about the various ways of access, about the requirements for using the data and about making applications, please refer to http://fdz.iab.de/de/FDZ Data Access.aspx and http://datasets.iza.org. 


\subsection{List of variables}

A detailed list of variables in the survey and administrative data can be found in the Apendix. It should be noted that several variables of the survey data are only available for specific subsamples. Several personality measures are only available for three cohorts of entry Nr. 1 (June 2007), Nr. 5 (October 2007) and Nr. 9 (February 2008). These variables are labeled as Modul A (MA) and Modul F (MF) in the corresponding overview in Table 6 in Section 7.2. Additionally, several questions that require good German language skills are only asked to respondents born in Germany. This applies for all variables from Modul F (MF). ${ }^{1}$ Moreover, some variables need to be adjusted in order to merge survey and administrative data (indicated by AD in Table 6) and some sensitive characteristics from the IZA ED Survey are excluded (indicated by NA in Table 6). Details can be found in Section 3.1.

${ }^{1}$ Details can be found in Arni et al. (2014) and the User Manual of the IZA ED Survey in http://idsc.iza.org/ed. 


\subsection{Volume Structure}

Table 2: File sizes in the IZA/IAB Linked Evaluation Dataset

\begin{tabular}{|l|l|l|}
\hline Dataset & File size & Checksum $^{\text {2 }}$ \\
\hline LED_9310_a_v3Th.dta & $5 \mathrm{MB}$ & f7574fa60f76807800f9f882fe282593 \\
\hline LED_9310_s_w1_Is.dta & $11 \mathrm{MB}$ & f0e6ff43aee36127fbf8cd79abece948 \\
\hline LED_9310_s_w1_qs.dta & $8 \mathrm{MB}$ & d1b6741b5721d1e3d2892fecb57b4231 \\
\hline LED_9310_s_iw_qs.dta & $1 \mathrm{MB}$ & 6c502b6d247963be60d694e3cc1b677e \\
\hline LED_9310_s_w2_Is.dta & $9 \mathrm{MB}$ & 7094829b21b5efc83b98e73dec925ca0 \\
\hline LED_9310_s_w2_qs.dta & $7 \mathrm{MB}$ & 36bc1ba610741627f8d8fbb88205d595 \\
\hline LED_9310_s_w3_Is.dta & $6 \mathrm{MB}$ & e08fd4dda47fab03f5dd417c1e33607e \\
\hline LED_9310_s_w3_qs.dta & 3 MB & d03b95a9f4e79e957e64984ebdcb3178 \\
\hline
\end{tabular}

2 The checksums are calculated for the Stata files by using the algorithm MD5. 


\section{Data sources and linkage}

\subsection{IZA ED Survey}

The IZA Evaluation Datasets (ED) Survey targets individuals who were freshly registered as unemployed at the German Federal Employment Agency within the period from June 2007 to May 2008. The contact information on individuals entering unemployment was drawn from the monthly unemployment inflow statistic (AST, Arbeitslosenstatistik) of the Federal Employment Agency. Based on these administrative records some restrictions (see Section 3.1) were implemented in order to pre-select the target population of "new" entries of individuals who are actively searching for a job and are eligible to participate in active labour market programs. These individuals were interviewed right at their entry into unemployment to achieve a reference measurement, which is important for the subsequent assessment of the impact of ALMP. To minimize the time lag between entry into unemployment and the first interview, the complete entry window of one year was disaggregated into 12 monthly entry cohorts.

The AST records individuals when they register as unemployed at either the Federal Employment Agency, if eligible for unemployment benefit type I, or the agency responsible for the unemployment benefit type II. While unemployment benefit type I is paid to individuals who made contributions to the unemployment insurance in the past, unemployment benefit type II is a means-tested, tax-funded benefit paid to long-term unemployed or individuals without any employment experience in the past (see Eichhorst, Grienberger-Zingerle and Konle-Seidl, 2010, for an overview on the German unemployment insurance system). Moreover, the AST is based on the concept of statistical months, which starts in the middle of a calendar month and ends in the middle of the following one. Based on the AST and its concept of statistical months, monthly cohorts of entries into unemployment are drawn by the Institute for Employment Research (IAB) in Nuremberg.

In order to reduce the sample size, random samples based on a "birthday concept" were drawn. Therefore, 34 separate days were randomly selected out of 365 days in the year, excluding February 29. This corresponds to a $9.32 \%$ sample of the total population of entrants into unemployment. The sampling scheme was designed to have an equal distance between the days, resulting in an equal distribution across the entire calendar year. Each person whose birthday falls on one of these sampling days and who entered unemployment between mid- 
May 2007 and mid-May 2008 is part of the sample. The birthday concept ensures a representative draw of a subsample from the AST. Finally, the survey institute infas ${ }^{3}$ received the selected subsample from the AST to contact the individuals for an interview (see Caliendo et al. 2011, for a detailed description of the sampling procedure).

\subsection{Administrative data of the IEB}

The administrative individual data were drawn from the Integrated Employment Biographies (IEB) of the IAB. They unite data from five different data sources, each of which may contain information from different administrative procedures.

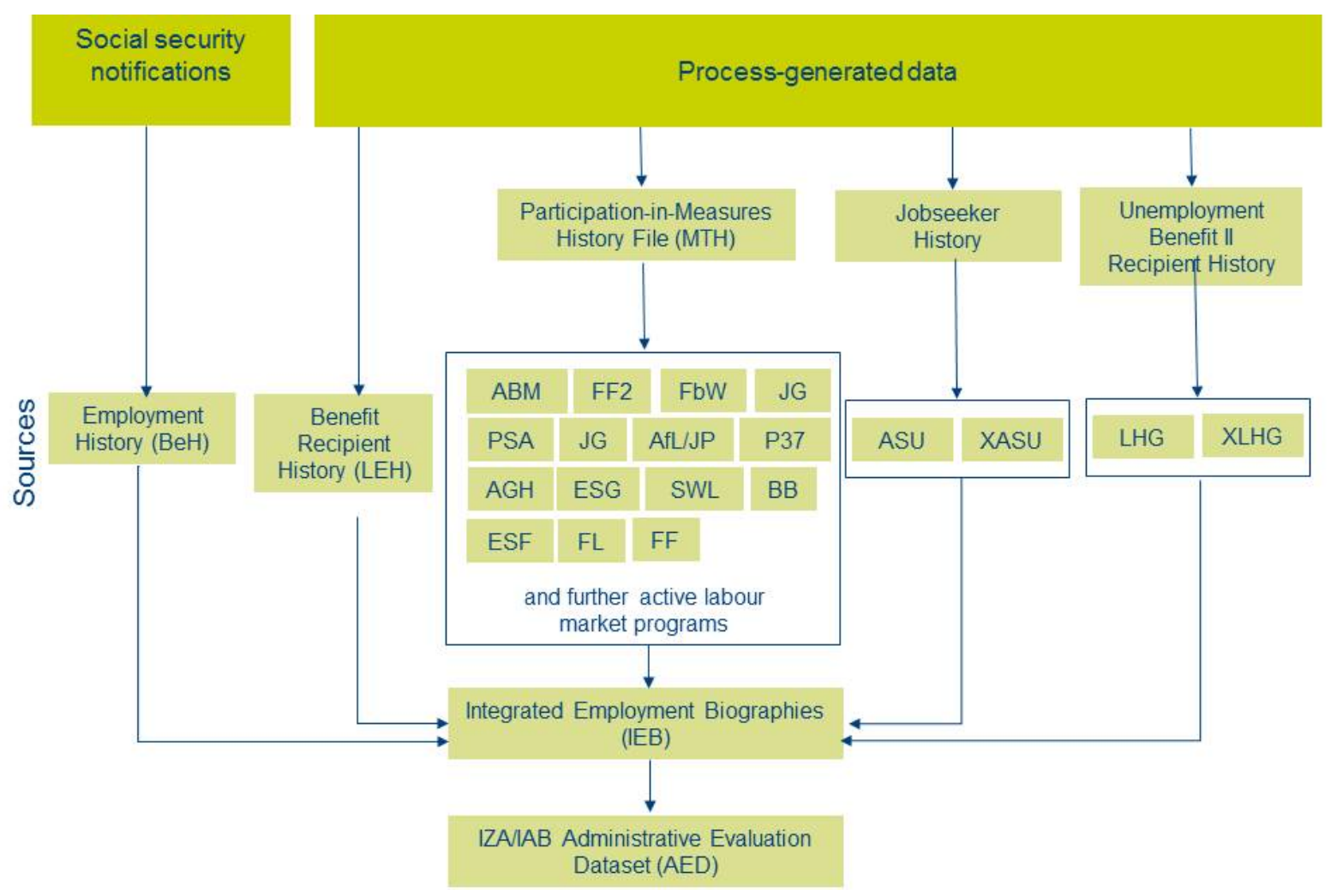

Figure 1: Data sources of the IZA/IAB Linked Evaluation Dataset (admin. data v3)

\subsubsection{Employee History (BeH)}

The source of data regarding employment is the Employment History (Beschäftigten-Historik $\mathrm{BeH}$ ) of the IAB. The data basis is the integrated notification procedure for health, pension and unemployment insurance, which came into effect as of 01 January 1973 (and was extended to cover Eastern Germany as of 01 January 1991), and is known by the abbreviation DEÜV

\footnotetext{
${ }^{3}$ Institute for Applied Social Sciences (infas) is a private and independent market and social research institution in Bonn, Germany.
} 
(previously DEVO / DÜVO) (for further details see: Bender et al. 1996, p. 4 et seq.; Wermter and Cramer 1988).

Under this procedure employers are required to submit notifications to the responsible social security agencies concerning all of their employees covered by social security at least once a year. The BeH covers all white- and blue-collar workers as well as apprentices as long as they are not exempt from social security contributions. This means that civil servants, self-employed persons and regular students (see Cramer 1985) are in principle not recorded in the BeH. Since the notification procedure was changed on 01 January 1999, employees in marginal part-time employment and unpaid family workers have also been recorded (not contained in the data until 01 April 1999). The data are recorded by the health insurance companies, collected and edited by the Federal Employment Agency (BA) and subsequently integrated into the History File by the IAB.

\subsubsection{Benefit Recipient History (LeH)}

The Benefit Recipient History (Leistungsempfänger-Historik - LeH) of the IAB covers periods during which individuals receive earnings replacement benefits from the Federal Employment Agency. These benefits comprise unemployment benefit, unemployment assistance and maintenance allowance, in other words not benefits under the sphere of Social Code Book II (e.g. unemployment benefit II). Since the entitlement to receive benefits depends on meeting certain legal requirements, unemployment periods in which the requirements are not met (e.g. no entitlement for receipt of benefits in case of unemployment assistance, or non-completion of the qualifying period for unemployment benefit) are not reported in the Benefit Recipient History.

\subsubsection{Unemployment Benefit II Recipient History (LHG I XLHG)}

The Unemployment Benefit II Recipient Histories (Leistungshistoriken Grundsicherung LHG / XLHG) contain the receipt of benefits in accordance with Social Code Book II (SGB II). This covers both basic social security benefits (e.g. unemployment benefit II) and supplements to unemployment benefit or additional benefits.

Unlike the benefits in the sphere of Social Code Book III, the BA is no longer necessarily the sole institution responsible for administering the benefits. The data therefore distinguish between the three possible types of institution responsible for implementing SGB II:

- Joint facilities (Gemeinsame Einrichtungen) / Cooperation of employment agencies and municipalities (Arbeitsgemeinschaften - ARGE, until the end of 2010) in which the BA and the municipality deal with tasks jointly, 
- Separated responsibilities (getrennte Trägerschaft) (until the end of 2011) - the tasks continue to be divided between the BA and the municipality ${ }^{4}-$,

- Authorised municipalities which are also called opting local authorities or opting municipalities according to the initial experimental clause of Section $6 \mathrm{a}$ - here the local authority is responsible for all tasks in the sphere of SGB II.

The data of the "Unemployment Benefit II Recipient History drawn from A2LL" (LHG) come from the BA administrative procedure A2LL, whilst the "Unemployment Benefit II Recipient History drawn from XLHG-BA-SGB II" (XLHG) records data which was reported in accordance with the transmission standard X-Sozial-BA-SBG II.

As a rule, A2LL is used until 2010 in all ARGE cooperation projects, and from 2011 onwards in joint facilities, whilst the standard X-Sozial-BA-SBG II is used by the authorised municipalities. Both of the procedures are used by municipalities with separated responsibilities.

An important difference compared with the LeH is that the amount of benefits received is not determined at the individual level but at the level of the benefit community (Bedarfsgemeinschaft $^{5}$ ). It is not possible, however, to link individuals with benefit receipt under SGB II at the level of benefit communities in the SIAB. The LHG and the XLHG in principle contain all registered individuals who are entitled to receive benefits in accordance with Section 7 SGB II, in other words, needy individuals who are capable of work and, if applicable, also the members of their benefit community. However, only periods during which a person is capable of work or is over the age of 65 are incorporated.

Each dataset depicts non-overlapping periods of entitlement to benefit of a person in a certain benefit community. A new observation starts for the following administrative reasons:

\footnotetext{
${ }^{4}$ The municipality pays the costs for housing and heating (Section 22 SGB II) and additional one-off benefit payments to cover extra costs (Section 23 (3) SGB II) and the additional benefits to support integration in accordance with Section 16 (2) Clause 2 No. 1 - 4 SGB II. The BA, on the other hand, covers the costs for regular benefits, social insurance contributions and integration benefits (SGB III and SGB II) and specific benefits excluding the additional benefits to support integration cited above.

${ }^{5}$ A so-called 'Bedarfsgemeinschaft', or 'benefit community', includes all individuals in a household who receive benefits jointly (i.e. as a joint payment). In the majority of cases, the 'benefit community' and the household will be the same, which in particular applies in the case of (married or unmarried) couples and parents with children under the age of 25 . However, under specific circumstances the 'benefit community' might not include all household members, or a household in which everybody receives benefit payments might be made up of more than one 'benefit community'. An example of the former is if a grown-up child lives with his/her parents and earns just enough to make his/her own living but has insufficient means to support his/her mother and father - in this case the 'benefit community' will only include the parents. An example of the latter is a three- (or more) generation household: since a 'benefit community' may only consist of two generations, this type of household will be made up of two such 'benefit communities', one consisting of the grandparent(s) and one of the parent(s) and child(ren). (Trappmann et al. 2007, p. 3)
} 
- on relevant birthdays $(14,15,18$ and 65$)$ of the members of a benefit community, which are statutory und relevant for structural changes of the benefit community (see Chapter 3.1.5),

- if there are changes in the composition of a benefit community (e.g. by members joining or leaving the benefit community),

- if there are changes in the variables of the benefit community client, and

- at the beginning and end of a sanction period for observations from 01 April 2006 onwards. However it must be taken into account that it is not possible to determine either the duration, the type of the sanction or the time when the sanction was imposed or when it began based on the data. The reason for this is the lack of a corresponding variable or value that indicates the start, the type or the duration of a sanction.

The LHG data are available from 01 January 2005, the XLHG data from 01 November 2005. However, until the beginning of 2007 both data sources are incomplete (see Chapter 4).

\subsubsection{Jobseeker History (ASU I XASU)}

Data about jobseekers are stored in the Jobseeker History (Arbeitsuchendenhistorik - ASU / XASU). The ASU data source contains information on jobseekers who are registered with employment agencies, and from 2005 onwards also includes ARGE cooperation projects and separated responsibilities for the implementation of SGB II. The XASU data source, on the other hand, contains the data of jobseekers in receipt of Unemployment Benefit II (ALG-II) from authorised municipalities from 2005 onwards. These data are reported in accordance with the X-Sozial-BA-SBG II standard.

\subsubsection{Participants-in-Measures History (MTH)}

The Participants-in-Measures History (Maßnahmenteilnahmehistorik - MTH) contains data on measures and participation in measures of active employment promotion. The basis of the data stock is information only on measures by providers making (or having made) use of the BA data collection procedures (agencies, joint facilities, ARGEs and separated responsibilities for the implementation of SGB II). Data from authorised local authorities which are not supplied via the BA transmission procedure are not contained in the $\mathrm{MTH}$, and are therefore not integrated in the underlying version of the IEB. For a more detailed description of the Participantsin-Measures History please refer to the FDZ-Datenreport 3/2015 (Eberle and Schmucker 2015). 


\section{Data preparation and sampling procedure}

\subsection{Sampling procedure and anonymization of the IZA ED Survey}

After the drawing of the gross sample (described in section 2.1) further restrictions of the sample are implemented. In order to ensure that the survey data contain the target population of job seekers freshly entering unemployment several further restrictions are implemented before the interview: 1) only individuals at prime working age (16-54 years at the entry unemployment) are considered for an interview, 2) recipients of unemployment benefits type II and 3) individuals re-entering unemployment after a period of sickness or participation in an ALMP program are excluded. Two further resrictions are implemented at the beginning of the interview: 1) the employment status and previous activities are verified and 2 ) individuals who signed a contract for a new job already at the entry into unemployment and hence do not search for employment are excluded. Further details with respect to the sampling procedure for the survey data can be found in Arni et al. (2014).

Moreover, several sensitive characteristics from the original survey data need to be excluded for the creation of the combined IZA/IAB Linked Evaluation Dataset. This involves mainly information related to the individual's migration background due to the relatively small sample for this subgroup of survey participants, and health conditions. Not included is the following information:

Table 3: Excluded Survey Information

\begin{tabular}{|l|l|}
\hline Variable (no.) & Description of variable \\
\hline $13 a$ & Country of school leaving qualification \\
$17 a$ & Country of vocational qualification \\
32 & Country of birth \\
33 & Year of immigration \\
35 & Date of receipt for german citizenship \\
37 & Citizenship other than German \\
38 & Date of receipt of citizenship other than German \\
39 & Number of citizenships other than German \\
42 & Country of birth: father \\
44 & Country of birth: mother \\
45 & Religious affiliation \\
46 & Type of religion \\
51 & Affiliation to German culture \\
$52 \_1$ & Affiliation with country of birth \\
$52 \_2$ & Attraction to cultures, traditions etc. \\
$57 a$ & Most common family language \\
$57 b$ & Second most common family language \\
\hline
\end{tabular}




\begin{tabular}{|l|l|}
\hline Variable (no.) & Description of variable \\
\hline $83 \_2$ & Country of origin: family of partner \\
84 & Country of birth: partner \\
$210 \mathrm{~b}$ & Case management II \\
303 & Health conditions \\
304 & Height in cm \\
305 & Weight in kg \\
306 & Health restrictions in last 2 months \\
310 & Smoking behavior \\
$310 \mathrm{~b}$ & Smoking behavior II \\
331 & Handicap \\
332 & Degree of handicap \\
1335 & Reasons for ending the self-employment \\
1346 & Reasons for ending internship / work experience \\
1610 & Type of activity other than employment (regular, marginal, self-), unem- \\
& ployment, ALMP participation, vocational education or school attendance \\
& (e.g. parental leave, military service, pension, period of sickness) \\
\hline
\end{tabular}

Several other survey information is included but needs to be adjusted for the linkage with the administrative records. This affects the following information:

Table 4: Adjusted Survey Information

\begin{tabular}{|c|c|c|c|}
\hline Variable (no.) & Description & Type of adjustment & Characteristics \\
\hline alo_quote & $\begin{array}{l}\text { Local unemploy- } \\
\text { ment rate at entry } \\
\text { into unemployment } \\
\text { at employment } \\
\text { agency district level }\end{array}$ & $\begin{array}{l}\text { Summarizing catego- } \\
\text { ries }\end{array}$ & $\begin{array}{ll}\text { West-Germany: } & <3 \% \\
& 3-6 \% \\
& 6-9 \% \\
& >9 \% \\
\text { East-Germany: } & <12 \% \\
& 12-14 \% \\
& 14-16 \% \\
& >16 \%\end{array}$ \\
\hline & Month, year of birth & $\begin{array}{l}\text { Age in years } \\
\text { Top coding }\end{array}$ & $\begin{array}{l}\leq 18 \\
19 \\
\ldots \\
55\end{array}$ \\
\hline $18 a 2$ & $\begin{array}{l}\text { Last net wage or } \\
\text { profit from self-em- } \\
\text { ployment }\end{array}$ & Top coding & \\
\hline $18 \mathrm{e}$ & $\begin{array}{l}\text { Reason for termi- } \\
\text { nation of last em- } \\
\text { ployment }\end{array}$ & $\begin{array}{l}\text { Summarizing catego- } \\
\text { ries }\end{array}$ & $\begin{array}{l}\text { Employee resigned } \\
\text { Employer resigned } \\
\text { Mutual agreement } \\
\text { Temporary contract }\end{array}$ \\
\hline
\end{tabular}




\begin{tabular}{|c|c|c|c|}
\hline Variable (no.) & Description & Type of adjustment & Characteristics \\
\hline & & & $\begin{array}{l}\text { Insolvency, close-down } \\
\text { Others }\end{array}$ \\
\hline 31 & Federal state & Dichotomization & $\begin{array}{l}\text { East-Germany } \\
\text { West-Germany }\end{array}$ \\
\hline 36 & $\begin{array}{l}\text { Citizenship other } \\
\text { than German }\end{array}$ & Dichotomization & $\begin{array}{l}\text { Yes } \\
\text { No }\end{array}$ \\
\hline 80 & Family status & $\begin{array}{l}\text { Summarizing catego- } \\
\text { ries }\end{array}$ & $\begin{array}{l}\text { Married or cohabiting } \\
\text { Single }\end{array}$ \\
\hline 85 & $\begin{array}{l}\text { Household size: } \\
\text { number of person }\end{array}$ & Top coding & $\begin{array}{l}1 \\
2 \\
3 \\
4 \\
5+\end{array}$ \\
\hline 86 & $\begin{array}{l}\text { Number of children } \\
\text { under age } 18 \text { in } \\
\text { household }\end{array}$ & Top coding & $\begin{array}{l}0 \\
1 \\
2+\end{array}$ \\
\hline 87 & $\begin{array}{l}\text { Age of children un- } \\
\text { der age } 18 \text { in } \\
\text { household }\end{array}$ & $\begin{array}{l}\text { Dichotomization for } 4 \\
\text { age categories }\end{array}$ & $\begin{array}{l}\text { 0-3 years: yes/no } \\
\text { 4-6 years: yes/no } \\
\text { 7-15 years: yes/no } \\
\text { 16-17 years: yes/no }\end{array}$ \\
\hline 88 & $\begin{array}{l}\text { Employment status } \\
\text { of partner }\end{array}$ & $\begin{array}{l}\text { Summarizing catego- } \\
\text { ries }\end{array}$ & $\begin{array}{l}\text { No partner } \\
\text { Part-time employed } \\
\text { Full-time employed } \\
\text { Apprenticeship } \\
\text { Unemployed } \\
\text { Others }\end{array}$ \\
\hline 90 & Monthly net income & $\begin{array}{l}\text { Categorization with } \\
\text { top/bottom coding }\end{array}$ & $\begin{array}{l}\leq 500 \\
\text { categories of at least } 500 \text { EUR } \\
>4000\end{array}$ \\
\hline $90 b$ & $\begin{array}{l}\text { Inquiry: gross or } \\
\text { net income }\end{array}$ & Top coding & \\
\hline 110 & $\begin{array}{l}\text { Employment status } \\
\text { before entry into } \\
\text { unemployment }\end{array}$ & $\begin{array}{l}\text { Summarizing catego- } \\
\text { ries }\end{array}$ & $\begin{array}{l}\text { Employed subject to social se- } \\
\text { curity } \\
\text { Subsidized employed } \\
\text { School, apprenticeship, military } \\
\text { etc. } \\
\text { Parental leave etc. } \\
\text { Others }\end{array}$ \\
\hline 1313 & $\begin{array}{l}\text { Net income (regular } \\
\text { employment) }\end{array}$ & Top coding & \\
\hline 1314 & $\begin{array}{l}\text { Sector (regular } \\
\text { employment) }\end{array}$ & Top coding & \\
\hline
\end{tabular}




\begin{tabular}{|l|l|l|l|}
\hline Variable (no.) & Description & Type of adjustment & Characteristics \\
\hline 1342 & $\begin{array}{l}\text { Net income (in- } \\
\text { ternship) }\end{array}$ & Top coding & \\
\hline
\end{tabular}

\subsection{Data preparation and anonymization of the administrative data}

\subsubsection{Description of the used original variables of the IEB}

Before the data from the data sources specified in Chapter 2 are merged to form the IEB they undergo source-specific correction procedures (for detailed imformation see Eberle and Schmucker, 2015). For the factual anonymization, the dataset contains only newly generated variables that were substantially transformed compared to the original variables of the IEB. $A$ detailed description of these recodings is given in the following sections.

\subsubsection{Original start date of observation (begorig)}

The original start date of the observation corresponds to the original start date of the notification. This can differ from the start date of the episodes (begepi). Because of the rules of the notification procedure, in BeH observations the starting and ending year are always identical (obligation of the employer to submit annual employment notifications).

Episodes with start date before 1993 have been deleted.

MTH: The characteristic usually describes the beginning of the participation in the measure. In case of measures such as the placement by third parties (Section 37), however, it is not the date the person appeared at the commissioned agent, but the date of assignment.

\subsubsection{Original end date of observation (endorig)}

The original end date of the observation corresponds to the original end date of the notification. This can differ from the end date of the relevant line of data, the so-called end date of the split episode.

Because of the rules of the notification procedure, in $\mathrm{BeH}$ observations the starting and ending year are always identical (obligation of the employer to submit annual employment notifications).

\subsubsection{Daily wage, daily benefit rate (tentgelt)}

1) $\mathrm{BeH}$ :

In BeH observations, this variable shows the employee's gross daily wage. It is calculated from the fixed-period wages reported by the employer and the duration of the (unsplit) original notification period in calendar days. The daily wage is shown in euros. 
Until 1998, employers in principle only reported the earnings which were subject to social security contributions. Earnings below the marginal part-time income threshold were not reported. Earnings exceeding the upper earnings limit for statutory pension insurance are only reported up to this limit. There are two upper earnings limits in the statutory pension insurance scheme. The earnings limit of the miners' pension insurance is generally higher than the earnings limit of the pension insurance for wage and salary earners. However, in the data a differentiation between these two insurance carriers is not possible.

Since the inclusion of marginal part-time employees in the employment notification procedure on 01 April 1999, earnings below the marginal part-time income threshold have also been recorded; the upper earnings limit still applies as the upper ceiling. In some cases, however, the reported earnings nonetheless exceed the upper earnings limit. Generally, this can probably be attributed to the payment of annual bonuses which the employer can add to the regular earnings in the annual, employment interruption or end of employment notifications. In this case, it is irrelevant whether the upper earnings limit in the statutory pension insurance which is decisive for the notification period is ex-ceeded as a result of this addition. However, such earnings notifications could also be due to incorrect details in the employment period. (The earnings information, however, may be considered less error-prone due to their insurance relevance.) The marginal part-time income threshold and the upper earnings limit for statutory pension insurance differ from year to year as well as between Eastern and Western Germany (the decisive factor is the location of the establishment). An overview of these limits and thresholds can be found under http://fdz.iab.de.

A daily wage reported as 0 euros can be put down to "employment interruption notifications". During these periods, the employment relationship continues to exist in legal terms, but without pay. This is the case for periods of illness after the end of continued payment of wages, for periods of maternity leave and for sabbaticals.

The daily wage is shown with two decimal places. All values greater than 0 and smaller than 0.01 were rounded up to 0.01 . This makes it possible to identify the above-mentioned employment interruption notifications with the condition daily wage $=0$.

2) LeH:

For LeH observations, the variable shows the daily benefit rate, converted into euros in each case. It must be taken into account that for observations with an original start date prior to 01 January 1998 the daily benefit rate applies to working days, while for observations with an original start date from 01 January 1998 onwards it applies to calendar days.

Since 01 January 2005, a daily benefit rate reported as 0 euros can be put down to benefit suspension periods or interruptions of benefit payments. If a reason for end of benefit is re- 
ported for an observation with a daily benefit rate equal to 0 , then it is a notification of interruption of benefit payments. In the case of observations that reflect a period of benefit suspension, the entitlement is the same as before the start of the benefit suspension period.

\subsubsection{Artificial establishment number (betnr)}

The artificial establishment number indicates which observations belong to the same estalishment. It is based on the establishment number allocated by the BA, which was replaced by an artificial number. (Further information on the allocation of establishment numbers by the BA can be found in Bender et al. 1996: p. 15 et seq. and pp. 27-30.)

For the establishment number, the following should be observed in general:

- If the company has one office only, or if the company has one office only in one municipality, this office is the establishment and receives an establishment number.

- If the company has several branch offices in one municipality, these establishment premises / workplaces must be merged in-to a single establishment under one establishment number, if they are part of the same economic class. Vice versa, if they are not part of the same economic class, each branch office is an establishment and receives an establishment number each.

- If the company has several branch offices in several municipalities, each of these branch offices is an establishment and receives an establishment number each.

In this context, the following definitions with regards to the allocation of establishment numbers as part of the notification procedure for social security must be observed:

- An establishment is a regionally and economically delimited unit in which employees work and to which, according to the above-mentioned principles, an establishment number is to be allocated.

- A workplace is a unit in which employees work and to which, according to the abovementioned principles, no establishment number is to be allocated.

- A company as a term combines establishment premises and workplaces of the same employer.

- An employer is any natural person or legal entity that employs at least one employee subject to social insurance contributions or in marginal part-time employment.

- Establishment and establishment premises are synonyms; branch office is a synonym for subsidiary, district office, out-sourced office, workplace, etc. if it is no establishment.

\subsubsection{Occupational status and working hours (stib)}

The employee's occupational status during the notification period is reported by the employer in the "employment details". The "occupational status" variable first distinguishes between full- 
time and part-time employees. The decisive factor here is the ratio between the contracted hours and the usual working hours in the establishment. The variable actually provides details about the occupational status for full-time employees only, whilst for part-time employees it only records whether their working hours exceed a certain limit or not. This limit was 20 hours of work per week until 1978, between 1979 and 1987 it was 15 hours per week, and since 1988 it has been 18 hours per week.

The distinction between blue-collar employees in full-time employment and white-collar employees centres solely on the type of pension insurance institution (Federal Social Insurance Office for Salaried Employees - BfA - for white-collar workers, and Land Social Insurance Office - LVA - for blue-collar workers). The "employees in vocational training" category covers not only trainees / apprentices, placement workers and interns but also semi-skilled trainees, students at colleges for health occupations and participants in subsidised further vocational training, retraining and induction training.

If more than one code is possible for an employee, the employer is required to classify the job according to the activity which is performed most. If this cannot be ascertained clearly, the code of the higher occupational status is to be entered (see Bundesagentur für Arbeit 2005, p. VI).

\subsubsection{Employment status (erwstat)}

This variable assumes different values with different meanings for each data source.

1) $\mathrm{BeH}$

For BeH observations, the variable contains the category of the employment notification, which was introduced along with the new notification procedure (DEÜV) as of 01 January 1999. It indicates contribution- or benefit-related particularities of the employment relationship. If multiple keys apply to an employment notification, the smallest must be indicated by the reporting employer. The majority of these cases are employment relationships subject to social security contributions without any exceptions which are kept under key number 101. Therefore, it is possible that these employees are slightly overestimated. The notification procedure states that changes in the employment status - e.g. when an apprentice is employed with his/her training company after completing his/her vocational training - must be indicated by a new notification (cf. Deutsche BKK 2012, p. 31).

The status can be contained in employment notifications that refer to the years prior to 1999 but were not received until 1999 or later. For notifications which were received before 1999, an attempt is made to allocate the notifications to the person groups on the basis of certain rules and with the aid of the 'school education and vocational training', 'occupational status and working hours' and 'occupation' variables as well as other information. In many cases, 
however, appropriate allocations are not possible. Since 01 April 1999, also employees in marginal part-time employment have been recorded in the DEÜV notification procedure. This group of people can be differentiated via the manifestations 109 and 209. For employees in marginal part-time employment, no data prior to the introduction of the notification obligation in 1999 could be collected.

\section{2) $\mathrm{LeH}$}

For LeH observations, the variable employment status contains the grouped benefit type. Thus, it can be differentiated whether a person receives unemployment benefit, unemployment assistance or maintenance allowance or whether contributions to private long-term care insurance are paid by the BA.

3) ASU / XASU

For ASU observations, the "employment status" variable reports the job search status. Recipients of unemployment benefits (Unemployment Benefit I or II) over the age of 58 who receive benefits under the relaxed conditions according to Section 428 of Social Code Book III (or Section 65 Para. 4 of Social Code Book II) and individuals aged over 58 who are not benefit recipients and are not willing to be placed in employment in the sense of Section 252 Para. 8 Social Code Book VI are recorded as individuals seeking advice.

In XASU observations, the variable employment status reports the "not unemployed, but registered as a job seeker" as well as "unemployed and registered as a job seeker" values.

4) LHG / XLHG

For LHG and XLHG datasets, the "employment status" characteristic shows whether the person is registered as underage employable, full-aged employable or not employable as of oldage pension threshold.

5) MTH

The characteristic defines the exact type of measure. Types of measures from the MTH ABM were divided into three successor products for participations in measures with beginning date after 01/07/2006: MTH ABMK, MTH BEH und MTH EXG.

\subsubsection{Place of residence: district (Kreis) (wo_kreis)}

In $\mathrm{BeH}$ and LeH observations, the place of residence at district level is only available for the years from 1999 onwards. The variable indicates the district (urban district or rural district) in which the social security contributor lives. The first two digits of the 5-digit district code (Kreisschlüssel) show the code for the federal state (Bundesland), positions 1-3 indicate the regional authority (Regierungsbezirk), and positions 1-5 show the district authority (Kreis). Federal states without a regional authority have a 0 in the third position. 
In the $\mathrm{BeH}$, the place of residence is determined at the end of each year and added consistently to all datasets of a year. For the LHG, XLHG and XASU sources, the place of residence applies to the period of the original observation. For the ASU and LeH, the characteristic contains the place of residence at the beginning of the original period of time.

In order to guarantee consistent regional allocations across the entire observation period, the information on the district was recoded with reference to the territorial allocation of 31 December 2010 for all sources, i.e. in all calendar years, a place of residence is assigned to a district in accordance with the boundaries that the district had on 31 December 2010. As the district boundaries have changed over time, cases would occur in which the district code changes without the individual concerned having relocated if the territorial allocations of the districts were not updated.

For observations with an original start date after 2010, the location data was set to "missing", because changes in the territorial allocation implemented from 2011 onwards cannot be recoded precisely to the allocation of 31 December 2010. For LHG, XLHG and XASU observations, the variable is available from 2005 onwards.

\subsubsection{Source of the observation (quelle)}

The variable indicates the data source.

\subsubsection{Type of termination of last job (art_kuend)}

This variable describes how the last employment or training relationship was terminated before a new period of job search. It can therefore be used to identify job-to-job placements.

\subsubsection{Data preparation}

For the creation of the IZA/IAB Linked Evaluation Dataset, the information of the administrative records are used to prepare a detailed set of variables that can be merged to the survey data without having spell-specific information that would allow to uniquely identify survey participants. These variables contain information on 1) labor market histories summarizing the last 10 years before the entry into unemployment, 2) characteristics of the last employment, 3) labor market outcomes, for a period of 30 months after the entry into unemployment, and 4) participation in ALMP programs during the unemployment spell.

Labor market histories are generated on a yearly base including information on months spent in regular employment, unemployment, ALMP programs and inactivity (this includes all possible states that are not observed in the administrative records). In order to capture some dynamic components of the labor market history the data contains additional information on changes of the employment status, like the number of unemployment spells or the number of 
employers, as well as information on the last job before the entry into unemployment. Moreover, information on average daily wages on a yearly base are summarized into adjusted quintiles (0-25 €; 25-40 €; 40-55 €; 55-75 €; $\geq 75 €)$.

Information on the last employment capture the earned wage on a daily base (top-coded at the social security contribution assessment ceiling), the length of the employment spell, the type of the job (full- or part-time) and the reason for the contract termination.

Labor market outcomes are prepared on a monthly base for a period of 30 months after the entry into unemployment. The length of the observation period corresponds to time between the entry into unemployment of the last cohort in May 2008 and end of the employment history (BeH) in December 2010. For each month, information on the employment status (regular employed, marginal employed or unemployed), the (categorized) weekly working time, working income and benefits are available. It should be noted that the underlying definition of (regular and marginal) employment requires an individual not to be in an ALMP program. Additionally, the information on an individual's place of residence is used to generate indicators for the moving behavior within 12 , respectively 30 months.

Finally, the administrative records are used to generate indicators for the participation in four different ALMP programs after entering unemployment. This involves short-term training measures (Trainingsmassnahmen), long-term training (Förderung beruflicher Weiterbildung), wage subsidies (Lohnkostenzuschuss, Eingliederungszuschuss) and start-up subsidies (Gründungszuschuss). For short- and long-term training, monthly information about the participation is included for the first 12 months after the entry into unemployment, while later periods are cumulated in order to ensure the factual anonymization of the data. For wage subsidies and start-up subsidies the months of the first payment of the subsidy, as well as the total number of months when the subsidy is received, are given. For reasons of data anonymization, these variables are summarized into three categories: 1 to 6 months; 7 to 9 months; 10 or more months.

The base for the construction of the individual characteristics is given by the source of the information (quelle) and the employment status (erwstat), while for all time-wise components the information of start dates (begorig), respectively end dates (endorig), of the spell-specific observation are used. For employer-related information, like the duration of the last employment spell, we additionally exploit the artificial establishment numbers, while several specific variables are used. An overview of all constructed administrative variables that are included in the dataset and underlying original variables are presented in Chapter 5. 


\subsection{Data linkage}

The IZA Evaluation Dataset provides the basis for the construction of the dataset. During the interview the survey participants are asked for their permission to merge the survey data with available administrative records of the IAB for scientific reasons. The exact wording of the question reads as follows:

"Before considering your professional career of the previous months, we have a favor to ask you. For the analysis of the data we would like to integrate excerpts from data that are available at the Institute for Employment Research (IAB) in Nuremberg. This refers, for example, to information about previous spells of employment or unemployment.

In order to merge these data to the survey data, the data protection law requires your permission. Hereby, I would like to ask you for this permission. When analyzing these data, it will be absolutely guaranteed that all data protection regulations will be adhered to.

Of course, your permission is voluntary and could be withdrawn at any time.

Do you agree, that these additional information will be merged to data gathered in this interview?"

Out of the 17,396 survey participants, actually included in the IZA Evaluation Dataset Survey, 15,274 persons (about $88 \%$ ) gave their permission to merge the survey to the administrative records. Additionally, 101 persons need to be excluded because they could not be uniquely identified in the administrative records. Therefore, the final dataset includes 15,173 individuals. All datasets can be merged by using the artificially generated individual ID (id).

\subsection{Missing values}

Missing values are coded as follows:

Table 5: Labeling of Missing Values

\begin{tabular}{|l|l|l|}
\hline Term & Value & Description \\
\hline $\begin{array}{l}\text { No (valid) details availa- } \\
\text { ble }\end{array}$ &.$z$ & $\begin{array}{l}\text { Values of a variable which are not systematically } \\
\text { missing, i.e. the variable is available in principle for } \\
\text { the data source, but no details are available for the } \\
\text { value considered or rather cannot be interpreted rea- } \\
\text { sonably. }\end{array}$ \\
\hline $\begin{array}{l}\text { Systematically not avail- } \\
\text { able }\end{array}$ &.$n$ & $\begin{array}{l}\text { A variable is not available in principle for a data } \\
\text { source or is not available for a certain period. }\end{array}$ \\
\hline
\end{tabular}




\section{Data quality and problems}

\subsection{IZA ED Survey}

The data quality, as well as problems due to panel attrition and survey non-response, are discussed in detail in Arni et al. (2014, Chapter 3) and the User Manual of the IZA ED Survey (http://idsc.iza.org/ed).

\subsection{Integrated Employment Biographies (IEB)}

Each of the different sources that make up the IEB shows specific data quality problems. A detailed description can be found in Eberle and Schmucker (2015). 


\section{Description of variables}

Frequency counts and overviews of the individual values and labels of the variables can be found in separate files under http://fdz.iab.de (see chapter 7 in the appendix).

\subsection{Identifiers}

\subsubsection{Artificial individual ID (id)}

\begin{tabular}{|l|l|}
\hline Variable label & Individual ID \\
\hline Variable name & id \\
\hline Category & identifiers \\
\hline Origin & BeH, LeH, LHG, XLHG, ASU, XASU, MTH \\
\hline Data type & numerical \\
\hline Hierarchy & none \\
\hline Detailed description & $\begin{array}{l}\text { The artificial individual ID indicates which observations belong to the } \\
\text { same person. Artificial means that it is not possible to infer any of the } \\
\text { person's characteristics or any original identifiers from this individual ID. } \\
\text { As there is no uniform individual identifier in the different data sources, } \\
\text { the allocation of the information from different data sources (e.g. em- } \\
\text { ployment and benefits) to individuals is not always unambiguous. In } \\
\text { such cases, implausible employment histories may arise. } \\
\text { The formation of the individual identifier which spans all data sources is } \\
\text { based on a heuristic developed by the BA. }\end{array}$ \\
\hline
\end{tabular}




\subsubsection{Month of entry into unemployment (eintritt)}

\begin{tabular}{|l|l|}
\hline Variable label & Month of entry into unemployment \\
\hline Variable name & eintritt \\
\hline Category & identifiers \\
\hline Origin & LeH, ASU \\
\hline Data type & date \\
\hline Hierarchy & none \\
\hline Detailed description & $\begin{array}{l}\text { Refers to month of entry into unemployment which determines the sur- } \\
\text { vey participation. The variable is a monthly date. In order to create an } \\
\text { artificial daily variable, Stata's dofm() function can be used. It is also } \\
\text { convenient when retrieving month and year as separate variables: } \\
\text { gen year = year(dofm(eintritt) } \\
\text { gen month = month(dofm(eintritt) })\end{array}$ \\
\hline
\end{tabular}

\subsection{Employment biography before unemployment}

\subsubsection{Months employed in year t-x (sv_jminus*)}

\begin{tabular}{|l|l|}
\hline Variable label & Months in employment subject to social security in year t-x \\
\hline Variable name & sv_jminus* \\
\hline Category & Employment biography before unemployment \\
\hline Origin & BeH \\
\hline Data type & Numerical \\
\hline Hierarchy & None \\
\hline Detailed description & $\begin{array}{l}\text { Refers to total number of months the individual spends in employment } \\
\text { subject to social security contributions within the corresponding year } x \\
\text { before the entry into unemployment. The information is available for val- } \\
\text { ues from } x=1 \text { to } x=10, \text { replacing the placeholder * in the actual variable } \\
\text { name. For example, } x=1 \text { corresponds to the last } 12 \text { months before the } \\
\text { entry into unemployment etc. }\end{array}$ \\
\hline
\end{tabular}




\subsubsection{Months unemployed in year t-x (alo_jminus*)}

\begin{tabular}{|l|l|}
\hline Variable label & Months unemployed in year t-x \\
\hline Variable name & alo_jminus* \\
\hline Category & Employment biography before unemployment \\
\hline Origin & LeH, ASU \\
\hline Data type & numerical \\
\hline Hierarchy & none \\
\hline Detailed description & $\begin{array}{l}\text { Refers to total number of months when the individual was registered as } \\
\text { unemployed within the corresponding year } x \text { before the entry into unem- } \\
\text { ployment. The information is available for values from } x=1 \text { to } x=10, r e- \\
\text { placing the placeholder * in the actual variable name. For example, } x=1 \\
\text { corresponds to the last } 12 \text { months before the entry into unemployment } \\
\text { etc. }\end{array}$ \\
\hline
\end{tabular}

\subsubsection{Months out of labor force in year t-x (olf_jminus*)}

\begin{tabular}{|l|l|}
\hline Variable label & Months out of labor force in year t-x \\
\hline Variable name & olf_jminus* \\
\hline Category & Employment biography before unemployment \\
\hline Origin & BeH, LeH, ASU \\
\hline Data type & numerical \\
\hline Hierarchy & none \\
\hline Detailed description & $\begin{array}{l}\text { Refers to total number of months the individual was inactive within the } \\
\text { corresponding year } x \text { before the entry into unemployment. This also in- } \\
\text { cludes periods during which the individual was self-employed or acted } \\
\text { as civil servant as this information is not included in the dataset. The } \\
\text { information is available for values from } x=1 \text { to } x=10, \text { replacing the place- } \\
\text { holder * in the actual variable name. For example, } x=1 \text { corresponds to } \\
\text { the last } 12 \text { months before the entry into unemployment etc. }\end{array}$ \\
\hline
\end{tabular}

\subsubsection{Months participated in a measure in year $t-x$ (mth_jminus*)}

\begin{tabular}{|l|l|}
\hline Variable label & Months participated in a measure in year t-x \\
\hline Variable name & mth_jminus* \\
\hline Category & Employment biography before unemployment \\
\hline Origin & MTH \\
\hline Data type & numerical \\
\hline Hierarchy & none \\
\hline Detailed description & $\begin{array}{l}\text { Refers to total number of months when the individual was registered in } \\
\text { any active labor market policy program within the corresponding year } x \\
\text { before the entry into unemployment. The information is available for val- } \\
\text { ues from } x=1 \text { to } x=10, \text { replacing the placeholder * in the actual variable } \\
\text { name. For example, } x=1 \text { corresponds to the last } 12 \text { months before the } \\
\text { entry into unemployment etc. }\end{array}$ \\
\hline
\end{tabular}




\subsubsection{Daily wage in year $t$ (tentgelt_q_jminus*)}

\begin{tabular}{|l|l|}
\hline Variable label & Daily wage in year t-x (quintiles) \\
\hline Variable name & tentgelt_q__minus* \\
\hline Category & Employment biography before unemployment \\
\hline Origin & BeH \\
\hline Data type & numerical \\
\hline Hierarchy & none \\
\hline Detailed description & $\begin{array}{l}\text { Refers to the average daily wage if the individual was employed within } \\
\text { the corresponding year } x \text { before the entry into unemployment. The in- } \\
\text { formation is available for values from } x 1 \text { to } x=10, \text { replacing the place- } \\
\text { holder * in the actual variable name. For example, } x=1 \text { corresponds to } \\
\text { the last } 12 \text { months before the entry into unemployment etc. } \\
5 \text { categories are constructed based on approximated quintiles. }\end{array}$ \\
\hline
\end{tabular}

\subsubsection{Number of employers last $t$ years ( $\left.n \_a g \_j m i n u s^{*}\right)$}

\begin{tabular}{|l|l|}
\hline Variable label & Number of employers last $\mathrm{t}$ years prior to entry into unemployment \\
\hline Variable name & n_ag_jminus* \\
\hline Category & Employment biography before unemployment \\
\hline Origin & BeH \\
\hline Data type & numerical \\
\hline Hierarchy & none \\
\hline Detailed description & $\begin{array}{l}\text { Refers to the total number of different employers within the last } \mathrm{t} \text { years } \\
\text { identified by differing establishment numbers. The variable is available } \\
\text { for values } \mathrm{t}=2 \text { and } \mathrm{t}=10 \text {, replacing the placeholder * in the actual variable } \\
\text { name. If } \mathrm{t}=2 \text {, the variable takes the value } 5 \text { for } 5 \text { or more different em- } \\
\text { ployers. If } \mathrm{t}=10 \text {, the variable takes the value } 10 \text { for } 10 \text { or more different } \\
\text { employers. }\end{array}$ \\
\hline
\end{tabular}

\subsubsection{Unemployment periods in last 2 years ( $\left.n \_a l o \_j m i n u s 2\right)$}

\begin{tabular}{|l|l|}
\hline Variable label & Unemployment periods last 2 years prior to entry into unemployment \\
\hline Variable name & n_alo_jminus2 \\
\hline Category & Employment biography before unemployment \\
\hline Origin & LeH, ASU \\
\hline Data type & numerical \\
\hline Hierarchy & none \\
\hline Detailed description & $\begin{array}{l}\text { Refers to the total number of different episodes within the last 2 years } \\
\text { during which the individual was registered as unemployed. The variable } \\
\text { takes the value 5 for 5 or more different unemployment episodes. }\end{array}$ \\
\hline
\end{tabular}


5.2.8 Number of measures joined last 2 years ( $\left.n \_m t h \_j m i n u s 2\right)$

\begin{tabular}{|l|l|}
\hline Variable label & $\begin{array}{l}\text { Number of measures joined last } 2 \text { years prior to entry into unemploy- } \\
\text { ment }\end{array}$ \\
\hline Variable name & n_mth_jminus2 \\
\hline Category & Employment biography before unemployment \\
\hline Origin & MTH \\
\hline Data type & numerical \\
\hline Hierarchy & none \\
\hline Detailed description & $\begin{array}{l}\text { Refers to the total number of different episodes within the last } 2 \text { years } \\
\text { when the individual participated in ALMP programs. The variable takes } \\
\text { the value } 5 \text { for } 5 \text { or more different ALMP episodes. }\end{array}$ \\
\hline
\end{tabular}

\subsubsection{Unemployment duration last episode of unemployment (dauer_alo_bev)}

\begin{tabular}{|l|l|}
\hline Variable label & Unemployment duration last episode of unemployment \\
\hline Variable name & dauer_alo_bev \\
\hline Category & Employment biography before unemployment \\
\hline Origin & LeH, ASU \\
\hline Data type & numerical \\
\hline Hierarchy & None \\
\hline Detailed description & $\begin{array}{l}\text { Refers to the total number of months of the duration of the last unem- } \\
\text { ployment spell before the current entry into unemployment. The variable } \\
\text { takes the value 25 for 25 or more months. }\end{array}$ \\
\hline
\end{tabular}

\subsection{Last employment before unemployment}

\subsubsection{Daily wage last employment (tentgelt_bev)}

\begin{tabular}{|l|l|}
\hline Variable label & $\begin{array}{l}\text { Daily wage last employment subject to social security (until contribu- } \\
\text { tion ceiling) }\end{array}$ \\
\hline Variable name & tentgelt_bev \\
\hline Category & Last employment before unemployment \\
\hline Origin & BeH \\
\hline Data type & numerical \\
\hline Hierarchy & None \\
\hline Detailed description & $\begin{array}{l}\text { Last daily income from employment. Top-coded at 149€, the daily equiv- } \\
\text { alent to the upper earnings limit in the statutory pension fund } 2007 \text { in } \\
\text { Eastern Germany. }\end{array}$ \\
\hline
\end{tabular}




\subsubsection{Full-time/Part-time last employment (vztz_bev)}

\begin{tabular}{|l|l|}
\hline Variable label & Full-time/Part-time last employment \\
\hline Variable name & Vztz_bev \\
\hline Category & Last employment before unemployment \\
\hline Origin & BeH \\
\hline Data type & numerical \\
\hline Hierarchy & None \\
\hline Detailed description & Dummy indicating if previous job was part-time employment. \\
\hline
\end{tabular}

\subsubsection{Days with last employer (dauer_ag_bev)}

\begin{tabular}{|l|l|}
\hline Variable label & Days with last employer \\
\hline Variable name & dauer_ag_bev \\
\hline Category & Last employment before unemployment \\
\hline Origin & BeH \\
\hline Data type & numerical \\
\hline Hierarchy & None \\
\hline Detailed description & $\begin{array}{l}\text { Refers to the overall time spent with the last employer since 1993 meas- } \\
\text { ured in days. The variable could refer to more than one employment } \\
\text { spell. }\end{array}$ \\
\hline
\end{tabular}

\subsubsection{Reason for end of previous employment (kuendigung)}

\begin{tabular}{|l|l|}
\hline Variable label & Reason for end of previous employment \\
\hline Variable name & kuendigung \\
\hline Category & Last employment before unemployment \\
\hline Origin & BeH \\
\hline Data type & Numerical \\
\hline Hierarchy & None \\
\hline Detailed description & Dummy indicating if individual resigns himself in last job. \\
\hline
\end{tabular}




\subsection{Employment biography after entry in unemployment}

\subsubsection{Empl. subject to social security in month $t+x$ (sv_tplus_*)}

\begin{tabular}{|l|l|}
\hline Variable label & $\begin{array}{l}\text { Empl. subject to social security (excl. participation in measures) in } \\
\text { month } t+x\end{array}$ \\
\hline Variable name & sv_tplus_* \\
\hline Category & Employment biography after entry into unemployment \\
\hline Origin & BeH \\
\hline Data type & Numerical \\
\hline Hierarchy & None \\
\hline Detailed description & $\begin{array}{l}\text { Dummy indicating employment subject to social security contributions } \\
\text { without participating in any ALMP program simultaneously in month } x \\
\text { after the entry into unemployment. The information is available for val- } \\
\text { ues from } x=1 \text { to } x=30, \text { replacing the placeholder * in the actual variable } \\
\text { name. }\end{array}$ \\
\hline
\end{tabular}

\subsubsection{Marginally employed in month $t+x$ (gf_tplus_*)}

\begin{tabular}{|l|l|}
\hline Variable label & Marginally employed in month $\mathrm{t+x}$ \\
\hline Variable name & gf_tplus_* \\
\hline Category & Employment biography after entry into unemployment \\
\hline Origin & BeH \\
\hline Data type & Numerical \\
\hline Hierarchy & None \\
\hline Detailed description & $\begin{array}{l}\text { Dummy indicating marginal employment without participating in any } \\
\text { ALMP program simultaneously in month } x \text { after the entry into unemploy- } \\
\text { ment. The information is available for values from } x=1 \text { to } x=30 \text {, replacing } \\
\text { the placeholder * in the actual variable name. }\end{array}$ \\
\hline
\end{tabular}

\subsubsection{Unemployed in month $\mathrm{t}+\mathrm{x}$ (alo_tplus_*)}

\begin{tabular}{|l|l|}
\hline Variable label & Unemployed in month $t+x$ \\
\hline Variable name & alo_tplus_* \\
\hline Category & Employment biography after entry into unemployment \\
\hline Origin & ASU \\
\hline Data type & Numerical \\
\hline Hierarchy & None \\
\hline Detailed description & $\begin{array}{l}\text { Dummy indicating that individual was registered as unemployment in } \\
\text { month } x \text { after the entry into unemployment. The information is available } \\
\text { for values from } x=1 \text { to } x=30, \text { replacing the placeholder * in the actual } \\
\text { variable name. }\end{array}$ \\
\hline
\end{tabular}


5.4.4 Hours worked per week in month t+x (azeit_kat_tplus_*)

\begin{tabular}{|l|l|}
\hline Variable label & Hours worked per week time in month t \\
\hline Variable name & azeit_kat_tplus_* \\
\hline Category & Employment biography after entry into unemployment \\
\hline Origin & BeH \\
\hline Data type & Numerical \\
\hline Hierarchy & None \\
\hline Detailed description & $\begin{array}{l}\text { Refers to the weekly working hours in month } x \text { after the entry into unem- } \\
\text { ployment. The information is available for values from } x=1 \text { to } x=30, \text { re- } \\
\text { placing the placeholder * in the actual variable name. }\end{array}$ \\
\hline
\end{tabular}

\subsubsection{Daily wage in month $t+x$ (geldbeh_tplus_*)}

\begin{tabular}{|l|l|}
\hline Variable label & Daily wage from employment subject to social security in month $t+x$ \\
\hline Variable name & geldbeh_tplus_* \\
\hline Category & Employment biography after entry into unemployment \\
\hline Origin & BeH \\
\hline Data type & Numerical \\
\hline Hierarchy & None \\
\hline Detailed description & $\begin{array}{l}\text { Refers to the average daily wage from employment subject to social se- } \\
\text { curity contributions in month } x \text { after the entry into unemployment. The } \\
\text { information is available for values from } x=1 \text { to } x=30, \text { replacing the place- } \\
\text { holder * in the actual variable name. Top-coded at 149€, the daily equiv- } \\
\text { alent to the upper earnings limit in the statutory pension fund } 2007 \text { in } \\
\text { Eastern Germany. }\end{array}$ \\
\hline
\end{tabular}

\subsubsection{Daily benefit in month $t+x$ (geldleh_tplus_*)}

\begin{tabular}{|l|l|}
\hline Variable label & Daily benefit in month $t+x$ \\
\hline Variable name & geldleh_tplus_* \\
\hline Category & Employment biography after entry into unemployment \\
\hline Origin & BeH \\
\hline Data type & Numerical \\
\hline Hierarchy & None \\
\hline Detailed description & $\begin{array}{l}\text { Refers to daily transfer payments (unemployment insurance and welfare } \\
\text { benefits) in month } x \text { after the entry into unemployment. The information } \\
\text { is available for values from } x=1 \text { to } x=30, \text { replacing the placeholder * in } \\
\text { the actual variable name. }\end{array}$ \\
\hline
\end{tabular}




\subsubsection{Change of home district during first x months (umzug_tplus*)}

\begin{tabular}{|l|l|}
\hline Variable label & $\begin{array}{l}\text { Change of home district during first } x \text { months after entry into unem- } \\
\text { ployment }\end{array}$ \\
\hline Variable name & umzug_tplus* \\
\hline Category & Employment biography after entry into unemployment \\
\hline Origin & BeH \\
\hline Data type & Numerical \\
\hline Hierarchy & None \\
\hline Detailed description & $\begin{array}{l}\text { Dummy indicating whether the job seeker changed his/her place of res- } \\
\text { idence (district) between the entry into unemployment and month } x \text { after } \\
\text { the entry. The information is available for values } x=12 \text { and } x=30, \text { replac- } \\
\text { ing the placeholder * in the actual variable name. }\end{array}$ \\
\hline Notes on quality & $\begin{array}{l}\text { Missing values if the place of residence is not available for the month of } \\
\text { entry into unemployment. }\end{array}$ \\
\hline
\end{tabular}

\subsubsection{Participation: training measure in month $t+x$ (training_tplus*)}

\begin{tabular}{|l|l|}
\hline Variable label & Participation: training measure in month $\mathrm{t}+\mathrm{x}$ \\
\hline Variable name & training_tplus* \\
\hline Category & Employment biography after entry into unemployment \\
\hline Origin & MTH \\
\hline Data type & Numerical \\
\hline Hierarchy & None \\
\hline Detailed description & $\begin{array}{l}\text { Dummy indicating whether the job seeker participated in a short-term } \\
\text { training program in month } x \text { after the entry into unemployment. Monthly } \\
\text { information are available for values } x=1 \text { to } x=12 \text {, replacing the place- } \\
\text { holder * in the actual variable name. For } x>12 \text { information are cumulated } \\
\text { into longer periods: } x=13 \_15 \text { (Month } 13 \text { to 15); } x=13 \text { 15 (Month 16 to } \\
18 \text { ); } x=19 \_30 \text { (Month 19 to 30) }\end{array}$ \\
\hline
\end{tabular}

\subsubsection{Participation: promotion of further vocational training in month $t+x$ (fbw_tplus*)}

\begin{tabular}{|c|c|}
\hline Variable label & Participation: promotion of further vocational training in month $t+x$ \\
\hline Variable name & fbw_tplus* \\
\hline Category & Employment biography after entry into unemployment \\
\hline Origin & MTH \\
\hline Data type & Numerical \\
\hline Hierarchy & None \\
\hline Detailed description & $\begin{array}{l}\text { Dummy indicating whether the job seeker participated in a long-term } \\
\text { training program (promotion of further vocational training) in month } x \text { af- } \\
\text { ter the entry into unemployment. Monthly information are available for } \\
\text { values } x=1 \text { to } x=12 \text {, replacing the placeholder * in the actual variable } \\
\text { name. For } x>12 \text { information are cumulated into longer periods: } x=13 \text { 15 } \\
\text { (Month } 13 \text { to } 15 \text { ); } x=13 \_15 \text { (Month } 16 \text { to } 18 \text { ); } x=19 \text { 24 (Month } 19 \text { to } 24 \text { ); } \\
x=25 \_30 \text { (Month } 25 \text { to } 30 \text { ) }\end{array}$ \\
\hline
\end{tabular}




\subsubsection{Month of first receipt of wage subsidy after entry into unemployment (lkz_beg)}

\begin{tabular}{|l|l|}
\hline Variable label & Month of first receipt of wage subsidy after entry into unemployment \\
\hline Variable name & lkz_beg \\
\hline Category & Employment biography after entry into unemployment \\
\hline Origin & MTH \\
\hline Data type & Numerical \\
\hline Hierarchy & None \\
\hline Detailed description & $\begin{array}{l}\text { Refering to the first month after the entry into unemployment when a } \\
\text { wage subsidy is paid off. }\end{array}$ \\
\hline
\end{tabular}

\subsubsection{Number of months with receipt of wage subsidy (Ikz_gesamt)}

\begin{tabular}{|l|l|}
\hline Variable label & Number of months with receipt of wage subsidy \\
\hline Variable name & Ikz_gesamt \\
\hline Category & Employment biography after entry into unemployment \\
\hline Origin & MTH \\
\hline Data type & Numerical \\
\hline Hierarchy & None \\
\hline Detailed description & $\begin{array}{l}\text { Refering to the cumulated number of months when a wage subsidy was } \\
\text { paid off within 30 months after the entry into unemployment. }\end{array}$ \\
\hline
\end{tabular}

\subsubsection{Month of first receipt of start-up subsidy after entry into unemployment}

(gz_beg)

\begin{tabular}{|l|l|}
\hline Variable label & Month of first receipt of start-up subsidy after entry into unemployment \\
\hline Variable name & gz_beg \\
\hline Category & Employment biography after entry into unemployment \\
\hline Origin & MTH \\
\hline Data type & Numerical \\
\hline Hierarchy & None \\
\hline Detailed description & $\begin{array}{l}\text { Refering to the first month after the entry into unemployment when a } \\
\text { start-up subsidy is paid off. }\end{array}$ \\
\hline
\end{tabular}


5.4.13 Number of months with receipt of start-up subsidy (gz_gesamt)

\begin{tabular}{|l|l|}
\hline Variable label & Number of months with receipt of start-up subsidy \\
\hline Variable name & gz_gesamt \\
\hline Category & Employment biography after entry into unemployment \\
\hline Origin & MTH \\
\hline Data type & Numerical \\
\hline Hierarchy & None \\
\hline Detailed description & $\begin{array}{l}\text { Refering to the cumulated number of months when a start-up subsidy } \\
\text { was paid off within } 30 \text { months after the entry into unemployment. The } \\
\text { variable takes the values 0 for 0 months, 1 for 1-6 months, 2 for 7-9 } \\
\text { months and 3 for } 10 \text { and more months. }\end{array}$ \\
\hline
\end{tabular}




\section{References}

Arni, Patrick; Caliendo, Marco; Künn, Steffen; Zimmermann, Klaus F. (2014): The IZA Evaluation Dataset Survey. A Scientific Use File. IZA Journal of European Labor Studies 3(6).

Bender, Stefan; Hilzendegen, Jürgen; Rohwer, Götz; Rudolph, Helmut (1996): Die IABBeschäftigtenstichprobe 1975-1990. Beiträge zur Arbeitsmarkt- und Berufsforschung 197, Nürnberg.

vom Berge, Philipp; König, Marion; Seth, Stefan (2013): Stichprobe der Integrierten Arbeitsmarktbiografien (SIAB) 1975-2010 Version 1 (SIAB 7510_DE_v1_dok1). FDZDatenreport 01/2013 (de), Nürnberg.

Bundesagentur für Arbeit (Hg.) (2005): Schlüsselverzeichnis für die Angaben zur Tätigkeit in den Meldungen zur Sozialversicherung. Ausgabe Januar 2005, Nürnberg.

Caliendo, Marco; Falk, Armin; Kaiser, Lutz C.; Uhlendorff, Arne; van den Berg, Gerard J.; Zimmermann, Klaus F. (2011): The IZA Evaluation Dataset: Towards Evidence-Based Labor Policy-Making. International Journal of Manpower 32.7 731-752

Cramer, Ulrich (1985): Probleme der Genauigkeit der Beschäftigtenstatistik. In: Allgemeines Statistisches Archiv 69: S. 56-68.

Deutsche BKK (2012): Ratgeber Sozialversicherung 2012, Wolfsburg, 56 S., URL: http://www.deutschebkk.de/fileadmin/user upload/Service/Download-Center/Ratgeber Sozialversicherung 2012 01.pdf, (Zugriff: 28.03.2012).

Eberle, Johanna; Schmucker, Alexandra (2015): IZA/IAB Administrative Evaluation Dataset (AED) 1993 - 2010. FDZ-Datenreport, 03/2015 (en), Nürnberg.

Eichhorst, Werner; Grienberger-Zingerle, Maria; Konle-Seidl, Regina (2010): Activation Policies in Germany: From Status Protection to Basic Income Support, German Policy, 6, 59100.

Trappmann, Mark; Christoph, Bernhard; Achatz, Juliane; Wenzig, Claudia (2007): Labour market and social security. A new panel study for research on German Social Code II.

Wermter, Winfried; Cramer, Ulrich (1988): Wie hoch war der Beschäftigtenanstieg seit 1983? - Ein Diskussionsbeitrag aus der Sicht der Beschäftigtenstatistik der Bundesanstalt für Arbeit. In: Mitteilungen aus der Arbeitsmarkt - und Berufsforschung 4/88, S. 468-482. 


\section{$7 \quad$ Appendix}

\subsection{Frequency tables}

Frequency tables and overviews of the individual values and labels of the variables can be found in separate files under:

http://doku.iab.de/fdz/reporte/2017/DR 02-17 frequencies labels de.zip http://doku.iab.de/fdz/reporte/2017/DR 02-17 frequencies labels en.zip

\subsection{List of variables}

\subsubsection{Survey data}

Table 6: Overview of Survey Variables ${ }^{6}$

\begin{tabular}{|c|c|c|}
\hline Variable (no.) & Descritipion & \\
\hline id & Artificial individual ID & \\
\hline int & Date of interview & \\
\hline cohort & Interview cohort & \\
\hline alo_quote & Local unemployment rate on employment agency district & AD \\
\hline $3 a$ & Month/year of birth of subject & AD \\
\hline \multirow[t]{2}{*}{10} & Gender of subject & \\
\hline & Entry into unemployment & \\
\hline 110 & Employment status before entry into unemployment & AD \\
\hline 112 & Duration of last employment according to question 110 & \\
\hline $18 \mathrm{a}$ & Ever employed before entry into unemployment & \\
\hline $18 a 1$ & Duration of employment according to question $18 \mathrm{a}$ & \\
\hline $18 a 2$ & Last net income from employment & AD \\
\hline $18 a 2 a$ & Duration of last employment & \\
\hline $18 a 3$ & Working time in last employment & \\
\hline 18a_k & Verification of income and working time & \\
\hline $18 \mathrm{e}$ & Reasons for termination of last employment before unemployment & AD \\
\hline $18 b$ & Lifetime employment & \\
\hline 18c & Number of employers before entry into unemployment & \\
\hline 18d & Lifetime employment: At least one year & \\
\hline $18 f$ & Unemployment before entry into unemployment & \\
\hline $18 \mathrm{~g}$ & Lifetime unemployment & \\
\hline $18 \mathrm{~h}$ & Number of unemployment spells before entry into unemployment & \\
\hline \multirow[t]{2}{*}{$18 \mathrm{i}$} & Lifetime unemployment: At least one year & \\
\hline & Migration & \\
\hline
\end{tabular}

${ }^{6} \mathrm{NA}$ refers to survey variables that are not included in the combined dataset, while AD refers to variables that needed to be adjusted due to data anonymization reasons. Details on the data adjustment can be found in Section 3.1. MA characterizes variables that are only available for three entry cohorts, while variables labeled by MF additionally require to be native German speaker. 


\begin{tabular}{|c|c|c|}
\hline 30 & Country of birth Germany & \\
\hline 31 & Federal State of birth within Germany & AD \\
\hline 32 & Country of birth & NA \\
\hline 33 & Year of migration & NA \\
\hline 34 & German citizenship & \\
\hline 35 & Date German citizenship & NA \\
\hline 36 & Other citizenship than German & AD \\
\hline 37 & Foreign citizenship & NA \\
\hline 38 & Date foreign citizenship & NA \\
\hline 39 & Number of further citizenships & NA \\
\hline 40 & Application for German citizenship & \\
\hline 41 & Father: Country of birth Germany & \\
\hline 42 & Father: Country of birth, open & NA \\
\hline 43 & Mother: Country of birth Germany & \\
\hline 44 & Mother: Country of birth, open & NA \\
\hline 45 & Religious affiliation & NA \\
\hline 46 & Type of religion & NA \\
\hline 47 & Religious intensity & NA \\
\hline 50 & MIG: Migration background & \\
\hline 51 & Affiliation to German culture & NA \\
\hline $52 \_1$ & Affiliation with country of birth & NA \\
\hline $52 \_2$ & Attraction to cultures, traditions etc. & NA \\
\hline 53 & Remain in Germany in future & \\
\hline 54 & Language ability: German & \\
\hline 55 & Language ability: English & \\
\hline 56 & Language spoken at home: German & \\
\hline $57 a$ & Language spoken at home: First language & NA \\
\hline $57 b$ & Language spoken at home: Second language & NA \\
\hline 58 & Language spoken with friends & \\
\hline \multirow[t]{2}{*}{530} & Cognitive test: List of animals & \\
\hline & School level and qualification & \\
\hline 11 & Highest level of school certificate & \\
\hline 12 & School certificate abroad/in Germany & \\
\hline $13 a$ & School certificate abroad: Country & NA \\
\hline 14 & Highest level of professional education & \\
\hline 16 & Professional education abroad/ in Germany & \\
\hline \multirow[t]{2}{*}{$17 a$} & Professional education abroad: Country & NA \\
\hline & $\begin{array}{l}\text { Professional situation: retrospective biographic longitudinal } \\
\text { section, starting at entry into unemploy- } \\
\text { ment } \\
12 \text { - Professional situati }\end{array}$ & \\
\hline \multirow[t]{2}{*}{1000} & Type of activity & \\
\hline & Block 12a: School attendance & \\
\hline 1101 & Duration & \\
\hline 1102 & Ongoing activity & \\
\hline 1103 & Planned/anticipated end & \\
\hline 1105 & Intended/received degree & \\
\hline 1106 & Financial support & \\
\hline \multirow[t]{2}{*}{1107} & Reasons for ending education & \\
\hline & Block 12b: Professional training / retraining & \\
\hline 1201 & Duration & \\
\hline 1202 & Ongoing activity & \\
\hline 1203 & Planned/anticipated end & \\
\hline 1210 & Type of training & \\
\hline 1204 & Search for training & \\
\hline
\end{tabular}




\begin{tabular}{|c|c|c|}
\hline 1204a & $\begin{array}{l}\text { Search for training assisted by friends/family members with migra- } \\
\text { tion background }\end{array}$ & \\
\hline 1205 & Financial support & \\
\hline $1206 a$ & Early termination of training & \\
\hline \multirow[t]{2}{*}{1206} & Reasons for ending training & \\
\hline & Block 12c: Employment & \\
\hline 1301 & Duration & \\
\hline 1302 & Ongoing activity & \\
\hline 1303 & Planned/anticipated end & \\
\hline \multirow[t]{2}{*}{1310} & Type of employment & \\
\hline & $\begin{array}{l}\text { Block 12c1: Dependent employment } \\
\text { Item X: employment subject to social security contribution } \\
\text { Item Y: marginal employment } \\
\text { Item Z: other type of employment }\end{array}$ & \\
\hline 1311 & Temporary & \\
\hline 1312 & Actual working time & \\
\hline 1313 & Net income & AD \\
\hline 1314 & Industry sector & AD \\
\hline 1315 & Public/private sector & \\
\hline 1316 & Firm size & \\
\hline 1317 & Job search & \\
\hline 1318 & $\begin{array}{l}\text { Job search assisted by friends/family members with migration } \\
\text { background }\end{array}$ & \\
\hline 1319 & Job finding & \\
\hline 1320 & $\begin{array}{l}\text { Job finding assisted by friends/family members with migration } \\
\text { background }\end{array}$ & \\
\hline \multirow[t]{2}{*}{1321} & Reasons for ending employment & \\
\hline & $\begin{array}{l}\text { Block 12c2: Public job creation scheme } \\
\text { Item R: 1-Euro-Job / work opportunity } \\
\text { Item S: job creation scheme }\end{array}$ & \\
\hline 1322 & Type/Content & \\
\hline 1312 & Actual working time & \\
\hline 1324 & Duration & \\
\hline 1325 & Income & \\
\hline 1326 & Search/ Assignment & \\
\hline 1327 & Qualification elements & \\
\hline 1328 & Subjective evaluation & \\
\hline \multirow[t]{2}{*}{1329} & Reasons for ending public employment scheme & \\
\hline & $\begin{array}{l}\text { Block 12c3: Self-employment } \\
\text { Item V: subsidized self-employment } \\
\text { Item S: unsubsidized self-employment }\end{array}$ & \\
\hline 1330 & Actual working time & \\
\hline 1331 & Income & \\
\hline 1332 & Start-up subsidy & \\
\hline 1333 & Industry sector & \\
\hline 1334 & Number of employees & \\
\hline \multirow[t]{2}{*}{1335} & Reasons for ending the self-employment & NA \\
\hline & $\begin{array}{l}\text { Block 12c4: Internship } \\
\text { Item T: employment trial period } \\
\text { Item S: internship }\end{array}$ & \\
\hline 1340 & Duration & \\
\hline 1341 & Actual working time & \\
\hline 1342 & Net income & AD \\
\hline 1343 & Industry sector & \\
\hline 1344 & Public/private sector & \\
\hline 1345 & Firm size & \\
\hline 1346 & Reasons for ending internship / work experience & NA \\
\hline
\end{tabular}




\begin{tabular}{|c|c|c|}
\hline & Block 12d: Unemployment & \\
\hline 1501 & Duration & \\
\hline 1502 & Ongoing activity & \\
\hline \multirow[t]{2}{*}{1503} & Benefits during unemployment & \\
\hline & Block 12e: Other activities & \\
\hline 1610 & Type of activity & NA \\
\hline 1601 & Duration, pension / early retirement & \\
\hline 1602 & Ongoing activity & \\
\hline 1603 & Planned/anticipated end & \\
\hline \multirow[t]{3}{*}{1604} & Benefits during unemployment & \\
\hline & End of longitudinal section & \\
\hline & Cross-sectional questions for ongoing unemployment spells & \\
\hline 120 & Subjective probability of ALMP participation ALMP & \\
\hline 121 & Job search behavior given ALMP participation & \\
\hline 122 & Subjective probability of ALMP participation by program type & \\
\hline \multirow[t]{2}{*}{123} & Subjective re-employment probability after ALMP participation & \\
\hline & Job search and reservation wage & \\
\hline \multirow[t]{2}{*}{130} & Searching for employment during unemployment & \\
\hline & Block 13a: Job search: Employment & \\
\hline 131 & Search channels & \\
\hline 131a & Search channel friends/family members with migration background & \\
\hline 132 & Type of job & \\
\hline 133 & Full-time or part-time job & \\
\hline 134 & Number of vacancies by Employment Agency & \\
\hline 135 & Number of applications & \\
\hline 136 & Number of applications: Relocation required & \\
\hline 137 & Job application: Distance & \\
\hline 138 & Job application: Distance in $\mathrm{km}$ & \\
\hline 139 & Subjective probability of finding a job & \\
\hline \multirow[t]{2}{*}{140} & Influence of Employment Agency in job finding & \\
\hline & Reservation wage & \\
\hline 141 & Expected wage & \\
\hline 142 & Expected wage: Expected working time & \\
\hline 143 & Acceptance of lower wage & \\
\hline 144 & Reservation wage & \\
\hline \multirow[t]{2}{*}{145} & Reservation wage: Expected working time & \\
\hline & Block 13b: Job search: Self-employment & \\
\hline 150 & Preparation & \\
\hline 151 & Financial support & \\
\hline \multirow[t]{2}{*}{152} & Relevance of financial support & \\
\hline & Reservation wage & \\
\hline 153 & Expected income & \\
\hline 154 & Expected income: Expected working time & \\
\hline 155 & Acceptance of lower income & \\
\hline 156 & Reservation income & \\
\hline 157 & Reservation income: Expected working time & \\
\hline
\end{tabular}




\begin{tabular}{|c|c|c|}
\hline & Block 13c: No job search & \\
\hline 160 & Reasons for not searching & \\
\hline \multirow[t]{2}{*}{161} & Last job search & \\
\hline & Personality/health & \\
\hline 300 & Willingness to take difficulties associated with job search & MA \\
\hline 520 & Cognitive test: Learning a list of words & MF \\
\hline 302 & Motivation to contact Employment Agency & MA \\
\hline 303 & Health condition & NA \\
\hline 304 & Height in $\mathrm{cm}$ & NA \\
\hline 305 & Weight in $\mathrm{kg}$ & NA \\
\hline 306 & Health restrictions in last 2 months & NA \\
\hline 307 & Emotional restrictions in last 2 months & MA \\
\hline 308 & Physical restrictions in last 2 months & MA \\
\hline 309 & Alcohol consumption & MA \\
\hline 310 & Smoking behavior I & NA \\
\hline $310 \mathrm{~b}$ & Smoking behavior II & NA \\
\hline \multirow[t]{2}{*}{311} & Psyche in last 2 months & MA \\
\hline & Networks & \\
\hline 70 & Contacts in the neighbourhood & \\
\hline 71 & Close friends outside the family & \\
\hline 72 & Number of close friends & \\
\hline 73 & $\begin{array}{l}\text { Frequency of contact with friends/family members before unem- } \\
\text { ployment }\end{array}$ & \\
\hline $73 \mathbf{a}$ & Contact with former colleagues before unemployment & \\
\hline 74 & Frequency contact with former colleagues: Migration background & \\
\hline $74 a$ & Share with migration background & \\
\hline 74b & $\begin{array}{l}\text { Frequency of contact with former colleagues with migration back- } \\
\text { ground }\end{array}$ & \\
\hline 75 & New acquaintances during unemployment & MF \\
\hline 76 & $\begin{array}{l}\text { New acquaintances during unemployment: Share of unemployed } \\
\text { people }\end{array}$ & MF \\
\hline \multirow[t]{2}{*}{77} & Volunteer work/political activities/self-help groups & \\
\hline & Household composition & \\
\hline 80 & Family status & AD \\
\hline 81 & Partner & \\
\hline 82 & Cohabitation & \\
\hline 83 & Partner born in Germany & \\
\hline $83 \_1$ & Partner: Family with migration background & \\
\hline $83 \_2$ & Partner: Country of origin of family & NA \\
\hline 84 & Partner: Country of origin & NA \\
\hline 88 & Partner: Employment status & AD \\
\hline 86 & Number of children under 18 in household & AD \\
\hline 87 & Age of children under 18 in the household & AD \\
\hline $89 \_1$ & Evaluation of the childcare situation in the household & \\
\hline $89 \_2 a$ & Caring for family members & \\
\hline 89_2b & Daily time spend caring for family members & \\
\hline 89_2c & Evaluation of care situation in the household & \\
\hline \multirow[t]{2}{*}{85} & Number of household members & AD \\
\hline & Household income & \\
\hline 90 & Monthly household net income & AD \\
\hline 91 & Household income I & \\
\hline 92 & Household income II & \\
\hline 93 & Household income III & \\
\hline 94 & Composition of household income & \\
\hline 540 & Cognitive test: Arithmetic problem I & MF \\
\hline 550 & Cognitive test: Arithmetic problem II & MF \\
\hline
\end{tabular}




\begin{tabular}{|c|c|c|}
\hline 560 & Cognitive test: Arithmetic problem III & MF \\
\hline & Debts & \\
\hline 100 & Debt repayment/financial solvency & \\
\hline 101 & Debts consequences & \\
\hline \multirow[t]{2}{*}{570} & Cognitive test: Remember list of words & MF \\
\hline & Cultural techniques & \\
\hline 315 & Television consumption & MF \\
\hline 316 & Daily activity: Getting out of bed & MF \\
\hline 317 & Daily activity: Cooking, personal hygiene etc. & MF \\
\hline 319 & Personal appearance & MF \\
\hline \multirow[t]{2}{*}{510} & Orientation in time & MF \\
\hline & Personality & \\
\hline 320 & Risk preferences & MF \\
\hline 321 & Social preferences & MF \\
\hline 322 & Patience & MF \\
\hline 323 & Reciprocity & MF \\
\hline 324 & Big Five & \\
\hline \multirow{2}{*}{325} & Locus of Control & \\
\hline & Life satisfaction / handicap & \\
\hline 330 & Life satisfaction & \\
\hline 331 & Handicap & NA \\
\hline \multirow[t]{2}{*}{332} & Degree of handicap & NA \\
\hline & Supervising institutions & \\
\hline 201a & Supervising institution & \\
\hline 201 & Contact with Employment Agency & \\
\hline 213 & Integration agreement & \\
\hline $210 a$ & Case management I & \\
\hline $210 b$ & Case management II & \\
\hline 19 & Driver's license & \\
\hline 20 & Availability of vehicle & \\
\hline 255 & Certificate of conduct/health I & \\
\hline 256 & Certificate of conduct/health II & \\
\hline 206 & Treatment by Employment Agency & \\
\hline 230 & Placement voucher & \\
\hline 231 & Placement voucher: Date & \\
\hline 232 & Placement voucher: Redemption & \\
\hline 233 & Placement voucher: Job offer & \\
\hline 234 & Placement voucher: Redemption & \\
\hline 241 & Education voucher & \\
\hline 241_b & Education voucher: Date & \\
\hline 242 & Education voucher: Redemption & \\
\hline \multirow[t]{2}{*}{243} & Education voucher: Reasons if not redeemed & \\
\hline & Benefit receipt & \\
\hline 220 & Type of benefit & \\
\hline 221 & Type of benefit by calendar month & \\
\hline 222 & Amount of last payment & \\
\hline 223 & Sanction & \\
\hline 224 & Sanction: Duration & \\
\hline 226 & Sanction: Amount & \\
\hline \multirow[t]{2}{*}{21} & Availability of means of communication & \\
\hline & Intergenerational transmission & \\
\hline $60 \mathrm{a}$ & Father: Age & \\
\hline 61a & Father: Upper secondary school degree (A-Levels) & \\
\hline $62 \mathrm{~b}$ & Father: Employed when respondent aged 15 & \\
\hline \multirow[t]{2}{*}{63} & Father: Occupational group & \\
\hline & Living circumstances & \\
\hline 65 & Type of residence & \\
\hline
\end{tabular}




\subsubsection{Administrative data}

Table 7: Overview of variables in the administrative data

\begin{tabular}{|c|c|}
\hline Variable & Label \\
\hline id & Individual ID \\
\hline eintritt & Month of entry into unemployment \\
\hline sv jminus* & Months in employment subject to social security in year t- $x$ \\
\hline alo jminus* & Months unemployed in year t-x \\
\hline olf jminus* & Months out of labour force in year $t-x$ \\
\hline mth_jminus* & Months participated in a measure in year $\mathrm{t}-\mathrm{x}$ \\
\hline tentgelt_q_jminus* & Daily wage in year t-x (quintiles) \\
\hline n_ag_jminus2 & Number of employers last 2 years prior to entry into unemployment \\
\hline n_ag_jminus10 & Number of employers last 10 years prior to entry into unemployment \\
\hline n_alo_jminus2 & Umemployment periods last 2 years prior to entry into unemployment \\
\hline $\mathrm{n} \_\mathrm{mth}$ jminus2 & Umemployment periods last 10 years prior to entry into unemployment \\
\hline dauer_alo_bev & Umemployment duration last episode of unemployment \\
\hline tentgelt_bev & Daily wage last employment subj. to social security (until contribution ceiling) \\
\hline vztz_bev & Full-time/Part-time last employment \\
\hline dauer_ag_bev & Days with last employer \\
\hline kuendigung & Reason for end of previous employment \\
\hline sv_tplus_* & Empl. subject to social security (excl. participation in measures) in month $t+x$ \\
\hline gf_tplus_* & Marginally employed in month $t+x$ \\
\hline alo_tplus_* & Unemployed in month $\mathrm{t}+\mathrm{x}$ \\
\hline azeit_kat_tplus_* & Hours worked per week in month $t+x$ \\
\hline geldbeh_tplus_* & Daily wage from employment subject to social security in month $t+x$ \\
\hline geldleh_tplus_* & Daily benefit in month $t+x$ \\
\hline umzug_tplus12 & Change of home district during first 12 months after entry into unemployment \\
\hline umzug_tplus30 & Change of home district during first 30 months after entry into unemployment \\
\hline training_tplus* & Participation: training measure in month $t+x(x=1 / 12,13-15,16-18,19-30)$ \\
\hline fbw_tplus1 & $\begin{array}{l}\text { Participation: promotion of further vocational training in month } t+x(x=1 / 12 \text {, } \\
13-15,16-18,19-24,25-30)\end{array}$ \\
\hline Ikz_beg & Month of first receipt of wage subsidy after entry into unemployment \\
\hline lkz_gesamt & Number of months with receipt of wage subsidy \\
\hline gz_beg & Month of first receipt of start-up subsidy after entry into unemployment \\
\hline gz_gesamt & Number of months with receipt of start-up subsidy \\
\hline
\end{tabular}




\section{List of Abbreviations}

AA Agentur für Arbeit / Arbeitsamt (Employment Agency)

ABM Arbeitsbeschaffungsmaßnahmen (job creation measures)

ABMK Klassische Arbeitsbeschaffungsmaßnahmen (classic job-creation measures)

AED Administrativer Evaluationsdatensatz (Administrative Evaluation Dataset)

AfL/JP Arbeit für Langzeitarbeitslose / Jump Plus (jobs for long-term unemployed persons / Jump Plus)

AGH Arbeitsgelegenheiten (job opportunities)

ALG Arbeitslosengeld (unemployment benefit)

ALMP Active Labour Market Policy/Policies

ARGE Arbeitsgemeinschaft ("workgroup")

AST Arbeitslosenstatistik

ASU Arbeitsuchendenhistorik (Jobseeker History)

A2LL Arbeitslosengeld II - Leistungen zum Lebensunterhalt (unemployment benefit II - benefits to secure a livelihood)

BA Bundesagentur für Arbeit (Federal Employment Agency)

BB Berufsberatung (vocational guidance)

BeH Beschäftigtenhistorik (Employee History)

BEB Berufseinstiegsbegleitung (career start mentoring)

BEH Betriebliche Einstellungshilfen (in-company employment grants)

BfA Bundesversicherungsanstalt für Angestelle (Federal Insurance Institution For Employees)

BHP Betriebs-Historik-Panel (Establishment History Panel)

BMAS Bundesministerium für Arbeit und Soziales (Federal Ministry for Labour and Social Affairs)

BNF Benachteiligtenförderung (promotion of the disadvantaged)

BvB Berufsvorbereitende Bildungsmaßnahmen (education measures for vocational preparation)

coArb Computerunterstützte Arbeitsvermittlung (operatives Verfahren zur Verwaltung der Vermittlung (Altverfahren)) (computer-aided job placement) (operative procedure for the placement management (old procedure))

DEÜV Verordnung über die Erfassung und Übermittlung von Daten für die Träger der Sozialversicherung - Datenerfassungs- und -übermittlungsverordnung (Regulation on the collection and transmission of data of the social security agencies) 
DEVO Zweite VO über die Erfassung von Daten für die Träger der Sozialversicherung und für die BA - Datenerfassungs-Verordnung (Second Regulation on the collection of data for the social security agencies and for the Employment Agency)

DÜvo Zweite VO über die Datenübermittlung auf maschinell verwertbaren Datenträgern im Bereich der Sozialversicherung und der BA - Datenübermittlungs-Verordnung (Second Regulation on the transmission of data for the social security agencies and for the Employment Agency)

ED IZA Evaluation Datasets

EDV Elektronische Datenverarbeitung (electronic data processing)

ESF Europäischer Sozialfonds (European Social Fund)

ESG Einstiegsgeld (integration subsidy)

EXG Existenzgründungszuschüsse (self-employment grants)

FbW Förderung beruflicher Weiterbildung (promotion of further vocational training)

FDZ Forschungsdatenzentrum der Bundesagentur für Arbeit am IAB (Research Data Centre of the Emplyoment Agency at the Institute for Employment Research)

FELEG Gesetz zur Förderung der Einstellung der landwirtschaftlichen Erwerbstätigkeit (act on the support in case of termination of farming activities)

FF $\quad$ Freie Förderung nach $\$ 10$ SGB III (discretionary support acc. to Section 10 Social Code Book III)

FF2 Freie Förderung nach §16f SGB II (discretionary promotion acc. to Section $16 f$ Social Code Book II)

fL flankierende Leistungen (supporting benefits)

gAw Träger mit getrennter Aufgabenwahrnehmung (separated responsibilities for the implementation of SGB II)

gE Gemeinsame Einrichtungen (joint facilities)

gT Getrennte Trägerschaft (separated responsibilities)

IAB Institut für Arbeitsmarkt- und Berufsforschung (Institute for Employment Research)

IABS IAB-Beschäftigtenstichprobe (IAB Employee Samples)

IDSC International Data Service Center of the Institute of Labor Economics (IZA)

IEB Integrierte Erwerbsbiografien (Integrated Employment Biographies)

infas Institut für angewandte Sozialwissenschaft (Institute for Applied Social Sciences)

ISIC International Standard Industrial Classification of All Economic Activities

isM individuelle sonstige Maßnahmen (individual other measures) 
ITM IT- und Informationsmanagement des Instituts für Arbeitsmarkt- und Berufsforschung (IT management of the IAB)

IZA Institut zur Zukunft der Arbeit (Institute of Labor Economics)

JG Jugendsofortprogramm (Immediate programme for youths)

LeH Leistungsempfängerhistorik (Benefit Recipient History)

LIAB Linked-Employer-Employee-Daten des IAB (Linked Employer-Employee Data from the $I A B$ )

LHG Leistungshistorik Grundsicherung (Unemployment Benefit II Recipient Histories)

LVA Landesversicherungsanstalt (insurance agency on a state level)

MOBI Mobilitätshilfen (mobility allowances)

MTH Maßnahmeteilnahmehistorik (participants-in-measures history)

NACE Nomenclature génerale des activités économiques dans les communautés européennes

P37 Beauftragung Dritter nach § 37 SGB III (placement services outsourced to third parties under Section 37 Social Code Book III)

P46 Aktivierung und berufliche Eingliederung nach §46 SGB III (activation of professional integration in accordance with Section 46 Social Code Book III)

PSA Personal Service Agentur (Personnel Service Agency)

SGB Sozialgesetzbuch (Social Code)

SIAB Stichprobe der Integrierten Arbeitsmarktbiografien (Sample of Integrated Labour Market Biographies)

SUF $\quad$ Scientific Use File

SWL Sonstige Weitere Leistungen (miscellaneous other benefits)

UBV Unterstützung von Beratung und Vermittlung (counseling and placement allowance)

VerBIS Vermittlungs- und Beratungsinformationssystems (placement and information system)

XASU Arbeitsuchendenhistorik aus XSozial-BA-SGB II (jobseeker history from XSozial-BA-SGB II)

XLHG Leistungsempfängerhistorik Grundsicherung aus XSozial-BA-SGB II (Benefit Recipient History from XSozial-BA-SGB II)

zkT Zugelassene kommunale Träger (authorised municipalities) 


\section{Imprint}

\section{FDZ-Datenreport 2/2017}

\section{Publisher}

The Research Data Centre (FDZ)

of the Federal Employment Agency

in the Institute for Employment Research

Regensburger Str. 104

D-90478 Nuremberg

\section{Editorial staff}

Dana Müller, Dagmar Theune

\section{Technical production}

Dagmar Theune

\section{All rights reserved}

Reproduction and distribution in any form, also in parts, requires the permission of FDZ

\section{Download}

http://doku.iab.de/fdz/reporte/2017/DR_02-17_EN.pdf

\section{Internet}

http://fdz.iab.de/

Corresponding author:

Alexandra Schmucker

Institute for Employment Research (IAB)

Research Data Centre (FDZ)

Regensburger Str. 104

D-90478 Nürnberg

Email: Alexandra.Schmucker@iab.de 